\title{
Selective Laser Melting of Aluminum and Titanium Matrix Composites: Recent Progress and Potential Applications in the Aerospace Industry
}

\author{
Eskandar Fereiduni *(D, Ali Ghasemi * and Mohamed Elbestawi \\ Department of Mechanical Engineering, McMaster University, Hamilton, ON L8S 4L7, Canada; \\ elbestaw@mcmaster.ca \\ * Correspondence: fereidue@mcmaster.ca (E.F.); ghasemia@mcmaster.ca (A.G.)
}

Received: 21 May 2020; Accepted: 9 June 2020; Published: 11 June 2020

\begin{abstract}
Selective laser melting (SLM) is a near-net-shape time- and cost-effective manufacturing technique, which can create strong and efficient components with potential applications in the aerospace industry. To meet the requirements of the growing aerospace industrial demands, lighter materials with enhanced mechanical properties are of the utmost need. Metal matrix composites (MMCs) are extraordinary engineering materials with tailorable properties, bilaterally benefiting from the desired properties of reinforcement and matrix constituents. Among a wide range of MMCs currently available, aluminum matrix composites (AMCs) and titanium matrix composites (TMCs) are highly potential candidates for aerospace applications owing to their outstanding strength-to-weight ratio. However, the feasibility of SLM-fabricated composites utilization in aerospace applications is still challenging. This review addresses the SLM of AMCs/TMCs by considering the processability (densification level) and microstructural evolutions as the most significant factors determining the mechanical properties of the final part. The mechanical properties of fabricated MMCs are assessed in terms of hardness, tensile/compressive strength, ductility, and wear resistance, and are compared to their monolithic states. The knowledge gained from process-microstructure-mechanical properties relationship investigations can pave the way to make the existing materials better and invent new materials compatible with growing aerospace industrial demands.
\end{abstract}

Keywords: aerospace; additive manufacturing (AM); selective laser melting (SLM); aluminum matrix composites (AMCs); titanium matrix composites (TMCs); in-situ/ex-situ reinforced composites; mechanical properties

\section{Introduction}

\subsection{Basic Concepts}

By increasing the technological requirements for lightweight materials with superior physical and mechanical properties, metal matrix composites (MMCs) are considered as novel engineering materials with tailorable properties, meeting a part of the growing industrial demands. Owing to their desired structural and functional properties, they have found their way into a wide variety of technological fields, specifically aerospace applications. MMCs are composed of at least two different constituents known as "matrix" and "reinforcement" whose properties complement each other. The combination of appropriate fracture toughness and ductility of the matrix, as well as the higher strength and modulus of the reinforcement in composites, leads to superior properties compared to those of individual constituents [1,2]. A wide variety of matrices including $\mathrm{Al}, \mathrm{Ti}, \mathrm{Fe}, \mathrm{Mg}, \mathrm{Co}, \mathrm{Zn}, \mathrm{Cu}$, and $\mathrm{Ni}$ as well as a broad range of ex-situ embedded or in-situ synthesized reinforcements including carbides (e.g., $\mathrm{WC}, \mathrm{SiC}, \mathrm{B}_{4} \mathrm{C}$, and $\mathrm{TiC}$ ), oxides (e.g., $\mathrm{Fe}_{3} \mathrm{O}_{4}, \mathrm{ZrO}_{2}$, and $\mathrm{Al}_{2} \mathrm{O}_{3}$ ), nitrides (e.g., $\mathrm{ZrN}, \mathrm{Si}_{3} \mathrm{~N}_{4}$, $\mathrm{TiN}$ ), borides 
(e.g., $\mathrm{TiB}, \mathrm{ZrB}_{2}, \mathrm{TiB}_{2}, \mathrm{WB}$ ) and different forms of carbon (e.g., graphite, carbon nanotubes (CNTs), graphene) [3-8] have been employed in the literature to fabricate MMCs. Given the higher specific strength (strength-to-weight ratio) and desired intrinsic properties, aluminum matrix composites (AMCs) and titanium matrix composites (TMCs) are considered as superseded candidates for the automotive and aerospace industries to fill the present technological gaps [9].

\subsection{Why Additive Manufacturing (AM) for Aerospace Applications?}

Since the components used in the aerospace industry are complex in geometry, their manufacturing through conventional processes is rather challenging or even impossible. To address this concern, advanced manufacturing routes are required to produce these components. In light of this scenario, additive manufacturing (AM) is the best choice for near-net-shape fabrication of parts with complex geometries. AM refers to a group of fabrication processes in which an object is manufactured through the deposition of subsequent layers of powder, wire, ribbon or liquid resin in a layer-by-layer or point-by-point manner [10]. AM machines use slicing algorithms to transform the three-dimensional (3D) computer-aided-design (CAD) model of a component into 2D sections, providing layer-by-layer fabrication of the desired component through bonding of subsequent layers. Currently, several AM techniques are commercially available for processing different types of materials, including metals, ceramics, and polymers. Depending on the material feedstock, source of energy, build volume, and physical state of material systems before or during the process, a wide variety of classifications have been proposed for AM processes [11]. ASTM F2792 is the most widely accepted standard which classifies AM processes into seven categories; namely, (i) binder jetting, (ii) material extrusion, (iii) material jetting, (iv) sheet lamination, (v) vat polymerization, (vi) powder bed fusion (PBF) and (vii) directed energy deposition (DED) [12]. Figure 1 shows a variety of additively manufactured parts applicable in the aerospace industry.

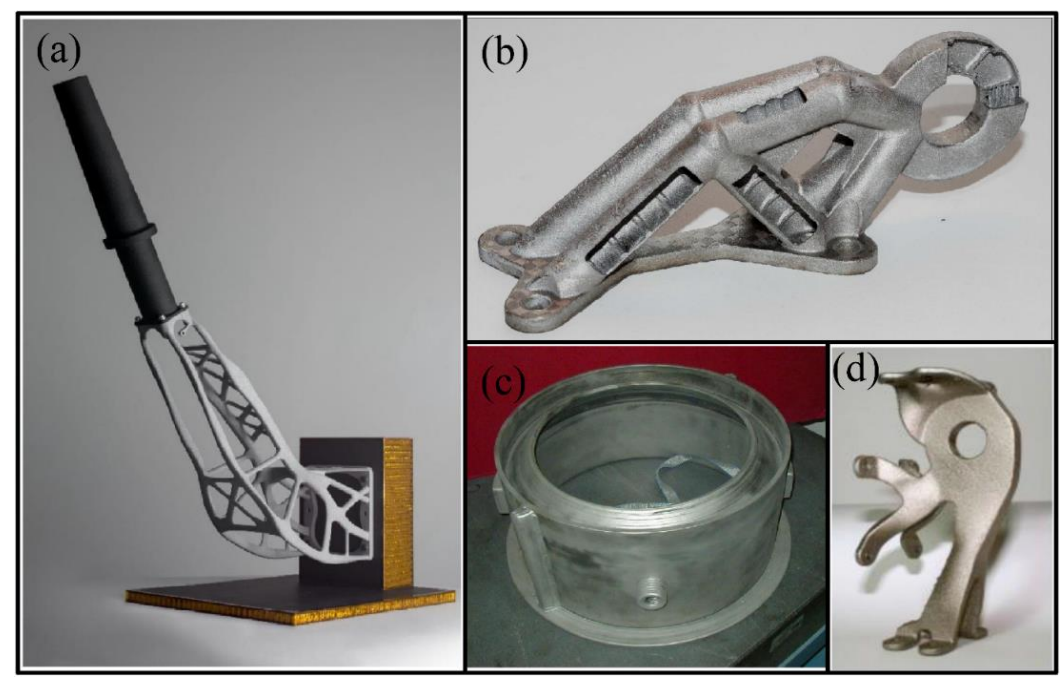

Figure 1. (a) Antenna support for Sentinel-1 fabricated by selective laser sintering of an aluminum-silicate-magnesium alloy $[13,14],(\mathbf{b})$ high-value aerospace bracket made of Ti-6Al-4V using selective laser melting [15], (c) flange fabricated by laser additive manufacturing of Inconel 718 [16], and (d) aircraft bracket manufactured by selective laser melting (SLM) processing of Ti-6Al-4V [17].

By having great potential in integrating various fields such as engineering design, laser technology, materials science, and mechanical engineering, AM technology has been accepted as a significant revolution in the manufacturing industry. This issue mainly lies in the ability of AM to fabricate near-net-shape components with complex geometries, leading to reduced lead-time, waste, and cost. This outstanding manufacturing technology has numerous potential benefits over other manufacturing methods, as outlined in the following: 
1. Production of complex geometries: The design freedom combined with the control over the movement of heat source, spot size, material feeding rate, and even the direction of deposition all associated with the AM technology are among the factors providing fabrication of parts with complex geometries (e.g., lattice structures). Moreover, since most of the components utilized in the aerospace industry are intricate in geometry, the AM technology can provide an exceptional opportunity to decrease the assembly cost $[18,19]$.

2. Minimized tooling requirements/operations: The single-stage and near-net-shape nature of the AM technology eliminates the need for multi-stage tooling [18]. However, the relatively poor surface quality of the AM-fabricated components may require post processing operations to reduce the surface roughness, especially in applications which are highly sensitive to the surface quality (e.g., aerospace industry). Machining, surface remelting, shot peening, sand blasting, laser sock peening and electrochemical polishing are the most frequently used post-processing methods.

3. Reduced time and cost: Due to the absence of expensive and dedicated tools such as molds and dies, AM technology provides exceptional technological opportunities for rapid and cost-effective fabrication of components in small volume production. Moreover, the lower buy-to-fly ratio of parts fabricated by AM compared to the conventional manufacturing processes significantly reduces the material waste and, consequently, the manufacturing cost [20,21].

4. Controlled atmosphere: The protected atmosphere involved in PBF-AM processes (especially the vacuum environment in electron beam melting (EBM)) makes it possible to process highly reactive and expensive high-temperature metals, which are usually difficult to process using conventional manufacturing routes. Moreover, the control over the atmosphere enables fabricating components with minimized defect levels (i.e., gas porosities and inclusions), which are of crucial importance in aerospace applications [22,23].

5. Flexibility in alloy design: AM technology can be rapidly utilized to explore the feasibility of using new materials for specific applications [24].

6. Superior mechanical properties: The significantly high cooling rates associated with AM processes lead to substantially refined microstructures with improved hardness and strength compared to those fabricated through conventional manufacturing routes [25].

7. Feasibility of fabricating functionally graded materials: The control over the process parameters as well as the material composition associated with some of the AM processes provides an outstanding opportunity to invent bimetals, multi-materials as well as functionally graded materials (FGMs) benefitting from the gradient change in composition and microstructure along the building direction [26].

8. Customized design: The ability to use customized mixtures of powders in AM facilitates fabricating $\overline{\mathrm{MMCs}}$ and functionally graded metal matrix composites with improved mechanical properties compared to the conventionally processed counterparts [27].

9. Environmentally friendly: AM technology is associated with relatively lower energy consumption and $\mathrm{CO}_{2}$ emission than conventional manufacturing processes [28,29].

\subsection{Requirements of Parts for Aerospace Applications}

Densification level: Porosities and cracks as the most common defects in additively manufactured parts adversely affect the densification level and, consequently, the mechanical properties. Due to the extremely localized and rapid heating/cooling nature in most of the AM processes, the defects formed by this manufacturing route have origins different from those observed in conventionally manufactured parts. Lack of fusion, incomplete penetration, balling phenomenon, spattering, keyhole effect, material evaporation, thermal stresses, and gas entrapment are the main reasons behind the formation of the defects [30-32]. The presence of even negligible amounts of defects in components applicable in the aerospace industry can lead to catastrophic failures since they act as crack nucleation sites during static and dynamic loadings, which deteriorates the fatigue and creep resistance significantly. To address this 
concern, several studies have been conducted to improve the density of additively manufactured parts by alleviating the formation of defects through optimizing the process variables, developing suitable post-processing techniques (i.e., hot isostatic pressing (HIP)) and applying powder/wire feedstocks with minimum residual gas (e.g., powders manufactured through plasma rotating electrode process (PREP)) [26-29].

Surface quality: Surface roughness is believed to be one of the major drawbacks of AM technology, especially in parts with intricate geometries which are difficult to be machined. Unmelted/partially melted powder particles [33], balling phenomenon [1,2], and stair-step effect [34] are the most common factors dictating the surface quality of the printed component. By serving as the crack nucleation site during cyclic loading (i.e., fatigue), surface roughness seems to be detrimental for aerospace applications [35]. In most cases, achieving a final part with surface roughness less than $1 \mu \mathrm{m}$ is impossible during AM processes. Therefore, the additively manufactured parts should experience surface treatments such as machining, grinding, chemical polishing, hot isostatic pressing, or shot peening to be suitable for the aerospace industry [18].

Strength-to-weight ratio: Increasing the strength of the material along with the weight reduction is the best strategy to enhance the fuel consumption efficiency and move towards the green aerospace vehicles with less detrimental impacts on the environment. That is why low-density structural materials, including Al- and Ti-based alloys are potential candidates for many aerospace applications [36].

Isotropic Properties: Although the AM technology provides fabrication of metallic parts with numerous benefits, the microstructural anisotropy, which is characterized by the grains elongated along the building direction, is a major limitation of the AM-fabricated components. The anisotropy in the microstructure and mechanical properties has been reported in the literature for a wide variety of AM-fabricated materials [37-40]. The main reason for this directional growth is the higher heat conduction in the building direction than other directions. While the AM-fabricated components may meet the requirements proposed by standards in their as-built condition, in some specific applications, post-processing heat treatments may be required to remove the anisotropy.

Wear resistance: Since several components, namely, shafts, valves, piston rods, and bearings, are subjected to wear in the service conditions, wear resistance needs to be taken into consideration [36]. Despite the noticeable progress in surface engineering, aiming at creating films on the surface of the parts to improve their wear resistance, most of the coating processes suffer from the inability to produce a thick film on the surface of the desired part. By providing the opportunity to create bi-materials, it is possible to fabricate structural components with tough bulk and modified hard surfaces (thick) with exceptional wear resistance [26].

Concerning the aircraft components such as engine (discs, blades and cooler parts), airframe, skin, landing gear wheel, flap and slat tracks of the wing [29], Ti and $\mathrm{Al}$ alloys are believed to be appropriate materials, as they allow substantial strength-to-weight saving and volume reduction. When being considered as the matrix for fabricating composites, the obtained TMCs and AMCs are expected to show even higher hardness, wear resistance, and strength-to-weight ratio, especially at elevated temperatures, meeting the above mentioned requirements [41,42]. Although fabrication of TMCs/AMCs by AM processes has been successfully reported in some research studies, the feasibility of utilizing these composite materials for aerospace applications is still an unanswered question. This review aims to address the selective laser melting (SLM) of TMCs and AMCs with potential applications in the aerospace industry. For this purpose, the production methods of the composite powders are introduced, and the requirements of an ideal composite powder for the SLM process is thoroughly discussed. The considerations existing in the selection of the starting reinforcing agent are explored. The primary processing and microstructural parameters influencing the final properties are thoroughly examined. The level of improvement in mechanical properties such as hardness, wear resistance, tensile/compressive strength, and ductility in composites compared to their monolithic system is assessed. The knowledge gained from process-structure-property relationship investigations 
can pave the way to make the existing materials better and invent new materials compatible with growing aerospace industrial demands.

\section{Selective Laser Melting for Fabricating MMCs}

\subsection{Background}

SLM is a PBF-AM process in which an object is manufactured layer-by-layer from a batch of loose powder using a mobile laser beam. In the SLM process, a 3D CAD model of an object is first designed and turned into 2D slices in the computer. Then, a thin layer of powder is deposited on the building platform, and a laser beam is used as the heat source to fuse selected regions of the powder layer and construct the first layer as the shape defined in the 2D slice. Afterward, the platform is lowered, and a new thin layer of powder is deposited. Again, the powders are fused by the laser beam and bonded to the bottom layer in pre-defined points. By repeating this process, complex-shaped objects could be constructed as defined by the model [43-46]. A schematic view of the SLM process setup is illustrated in Figure 2.

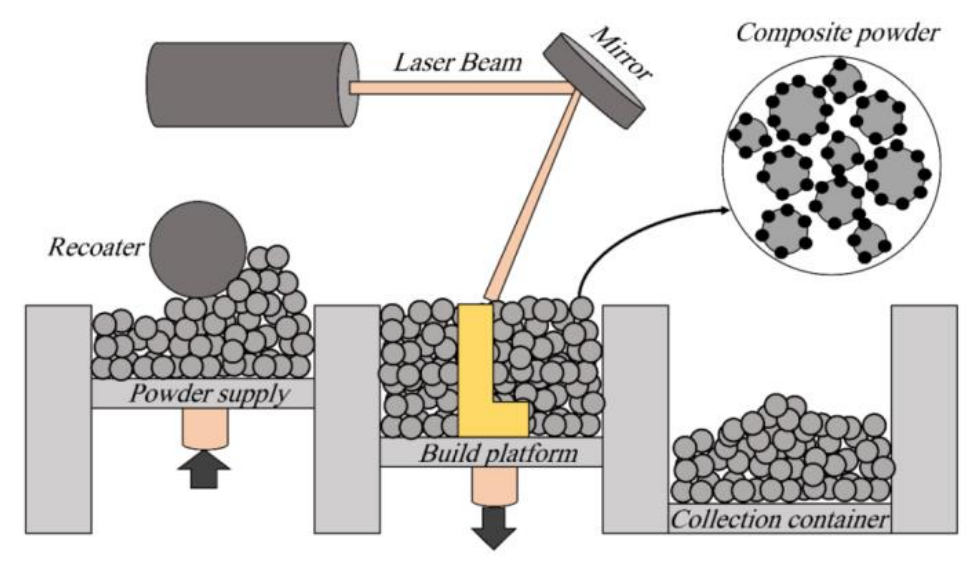

Figure 2. Schematic view illustrating the fabrication of composite parts by the SLM process.

Due to the layer-by-layer nature of the SLM process, it is capable of producing objects with complex shapes and geometries in bulk, porous, or cellular forms with potential applications in aerospace, biomedical, and automotive industries [47,48]. Moreover, the SLM process does not require special tools, making it an outstanding candidate for small volume production [48]. While a wide range of materials can be produced by the SLM process, there exist some difficulties with the processing of some intermetallic compounds and alloys with high melting temperatures. Among different materials, aluminum, titanium, and their alloys are interesting choices for the SLM process. Remarkably high heating and cooling rates of $\sim 10^{3}$ to $10^{6} \mathrm{~K} / \mathrm{s}$ associated with the SLM process provide the conditions for producing non-equilibrium phases with fine-grained microstructures in these alloys, leading to superior mechanical properties [49]. Moreover, incorporation of reinforcements into the aluminum and titanium alloy matrices to produce AMCs and TMCs can further enhance the mechanical and functional properties [48,50].

Among various reinforcements, discontinuous ceramic particles are the most frequently used materials incorporated into the $\mathrm{Al} / \mathrm{Ti}$ matrix to form $\mathrm{AMCs} / \mathrm{TMCs}$. However, carbonaceous materials (e.g., graphene and carbon nanotube $(\mathrm{CNT})$ ), metallic agents and ceramic precursors (e.g., $\mathrm{B}_{4} \mathrm{C}$ ) have been also used as the starting reinforcing particles. A literature review reveals that a wide variety of reinforcements have been employed to produce such composites using the $\mathrm{SLM}$ process. $\mathrm{TiC}^{\mathrm{TiB}} \mathrm{Ti}_{2}, \mathrm{SiC}$, $\mathrm{Al}_{2} \mathrm{O}_{3}, \mathrm{CNT}$ and graphene in the case of $\mathrm{AMCs}$, and $\mathrm{TiC}, \mathrm{TiB}_{2}$, and $\mathrm{B}_{4} \mathrm{C}$ in TMCs are the materials most frequently used as the starting reinforcing agent for fabricating composites through an SLM process. 


\subsection{Powders for SLM of MMCS}

\subsubsection{Methods}

Due to the absence of different nozzles for feeding composite constituents, fabrication of MMCs by the SLM process requires a composite powder feedstock as the starting material $[1,2,51,52]$ (Figure 2). The characteristics and behaviors of the developed composite powder are of crucial importance and significantly affect the quality of processed parts. When ceramic reinforcing particles are mixed with a metallic powder, the type, size, morphology, and volume fraction of these powder particles are among the crucial factors determining the laser absorptivity, processability, microstructural homogeneity, and, consequently, the mechanical properties of SLM-processed MMCs [53-55]. With a few exceptions, no commercial composite powder feedstock is currently available to manufacture MMCs using the SLM process. Accordingly, several routes have been utilized in recent years to pre-process powders and develop the desired composite powder feedstocks enabling fabrication of MMCs. The composite powder production routes can be classified into two main categories of mechanical and non-mechanical. The methods belonging to each category are summarized in Table 1 along with their advantages and disadvantages as well as typical micrographs of composite powders produced by them. Preserving the desired spherical shape of the metallic powder particles and their decoration by the second constituent are the main features of introducing the non-mechanically produced composite powder feedstocks suitable for SLM of MMCs. However, due to their higher practicality, time, and cost-efficiency and applicability to a wide range of materials, mechanical mixing methods have attracted a great deal of attention in recent years. That is why regular mixing and ball milling are known as the most applicable processes for pre-processing of composite powders. 
Table 1. The methods used to produce composite powders for selective laser melting (SLM) applications.

\begin{tabular}{|c|c|c|c|c|}
\hline Method & & Advantages & Disadvantages & Example \\
\hline \multirow{3}{*}{ Mechanical } & $\begin{array}{c}\text { Regular } \\
\text { mixing }\end{array}$ & $\begin{array}{c}\text {-Does not affect the characteristics of } \\
\text { starting powders } \\
\text {-Can be utilized to prepare a wide range } \\
\text { of powders } \\
\text {-Easy to use, fast, cost-effective and } \\
\text { noticeably productive }\end{array}$ & $\begin{array}{l}\text {-Limited capability to disperse guest } \\
\text { powder particles, leading to relatively } \\
\text { low poor guest-to-host adherence } \\
\text {-Requires noticeably long mixing times to } \\
\text { provide an acceptable dispersion state of } \\
\text { guest particles } \\
\text {-The produced composite powders are } \\
\text { not ideal in terms of powder packing }\end{array}$ & \\
\hline & & & & $\begin{array}{l}5 \text { wt. } \% \mathrm{~B}_{4} \mathrm{C} / \mathrm{Ti}-6 \mathrm{Al}-4 \mathrm{~V}[52] \text {. The } \\
\text { Ti- } 6 \mathrm{Al}-4 \mathrm{~V} \text { powder has been fabricated } \\
\text { by the gas atomization process. }\end{array}$ \\
\hline & $\begin{array}{l}\text { Ball } \\
\text { milling }\end{array}$ & $\begin{array}{c}\text {-Due to the presence of balls, requires } \\
\text { shorter mixing times compared to the } \\
\text { regular mixing } \\
\text {-Can be employed for a wide range of } \\
\text { materials } \\
\text { - Relatively fast and easy to use } \\
\text {-Can avoid agglomeration of guest } \\
\text { particles with a high cohesiveness } \\
\text {-The produced composite powders } \\
\text { typically show packing densities higher } \\
\text { than those obtained by regular mixing }\end{array}$ & $\begin{array}{c}\text {-Affects the characteristics of the starting } \\
\text { powder particles } \\
\text {-Requires protective environment for } \\
\text { highly reactive materials to avoid } \\
\text { oxidation } \\
\text {-The change in the particle morphology } \\
\text { caused by the ball milling can adversely } \\
\text { affect packing density and flowability of } \\
\text { the produced powder } \\
\text {-The wear of the balls or the container } \\
\text { wall during the mixing process may add } \\
\text { impurities to the powder }\end{array}$ & $\begin{array}{l}\text { (c) wt.\% } \mathrm{B}_{4} \mathrm{C} / \mathrm{Ti}-6 \mathrm{Al}-4 \mathrm{~V} \text { [52]. The } \\
\text { Ti-6Al-4V powder has been fabricated } \\
\text { by the gas atomization process. }\end{array}$ \\
\hline
\end{tabular}


Table 1. Cont.

\begin{tabular}{|c|c|c|c|c|}
\hline Method & & Advantages & Disadvantages & Example \\
\hline Non- Mechanical & $\begin{array}{c}\text { Flux-assisted } \\
\text { synthesis }\end{array}$ & $\begin{array}{c}\text {-Highly spherical powder particles are } \\
\text { achieved } \\
\text {-The guest particles are homogeneously } \\
\text { distributed in the composite powder } \\
\text { feedstock (also inside the host powder } \\
\text { particles) } \\
\text {-Can provide relatively high productivity } \\
\text {-The produced composite powders } \\
\text { benefit from high apparent packing } \\
\text { density and flowability }\end{array}$ & $\begin{array}{l}\text {-The powder production through this } \\
\text { method is more complicated than the } \\
\text { mechanical methods } \\
\text {-Applicable to limited numbers of } \\
\text { composite powder systems }\end{array}$ & $\begin{array}{l}\text { 11.6 wt. \% } \mathrm{TiB}_{2} / \mathrm{AlSi10 \textrm {Mg }} \text { [56]. The } \\
\text { last manufacturing step for the } \\
\text { production of composite powder is } \\
\text { gas atomization. }\end{array}$ \\
\hline & $\begin{array}{c}\text { Agent- } \\
\text { assisted } \\
\text { deposition }\end{array}$ & $\begin{array}{l}\text {-The desired spherical shape of host } \\
\text { powder particles is preserved } \\
\text {-The guest powder constituent shows a } \\
\text { homogeneous dispersion on the surface } \\
\text { of host powder particles } \\
\text {-Provides composite powders with } \\
\text { relatively high packing density and } \\
\text { flowability }\end{array}$ & -Relatively slow, complex and expensive & $\begin{array}{l}5 \text { wt. } \% \mathrm{Al}_{2} \mathrm{O}_{3}-0.15 \\
\text { wt.\%ATCNT/NiAlCrMo [57]. The } \\
\text { production method of the host alloy } \\
\text { powder has not been provided. }\end{array}$ \\
\hline
\end{tabular}


Table 1. Cont.

\begin{tabular}{|c|c|c|c|c|}
\hline Method & & Advantages & Disadvantages & Example \\
\hline & \multirow[t]{2}{*}{$\begin{array}{l}\text { Electroless } \\
\text { plating/ } \\
\text { Electrostatic } \\
\text { assembly }\end{array}$} & $\begin{array}{l}\text {-The spherical shape of host particles is } \\
\text { met or preserved. } \\
\text {-Provides acceptable attachment of guest } \\
\text { particles to the host ones }\end{array}$ & $\begin{array}{c}\text {-Low production rate } \\
\text {-Post-processing is required } \\
\text {-Expensive } \\
\text {-Requires a thorough selection of system } \\
\text { constituents and process variables }\end{array}$ & ${ }^{100}$ \\
\hline & & & & $\begin{array}{l}50 \text { vol. } \% \mathrm{Ni} / \mathrm{Al}_{2} \mathrm{O}_{3} \text { [58]. The host } \\
\text { powder particles are synthesized } \\
\text { during the production of the } \\
\text { composite powder. }\end{array}$ \\
\hline
\end{tabular}


The ball milling method (also known as mechanical alloying) is a technique that has been applied to improve the dispersion state of reinforcing particles in micro/nano-composite powders. This process is characterized by repeated deformation, cold-welding, and fracture of powder particles as a result of high energy impacts induced by the particle/particle and ball/particle collisions (Figure 3a) [59]. The selection of proper process parameters is of utmost importance to achieve the desired features of the mixed powder system and consequently obtain high-quality MMC parts. These parameters include rotational speed, mixing time, ball-to-powder weight ratio, and the employed milling time-pause cycle [52]. The regular mixing has the same concept as the ball milling process, with the only difference being that it is devoid of balls (Figure $3 b$ ). The absence of balls leads to the lack of decoration experienced by metallic powder particles, which in turn leads to the separation of different constituents during the powder deposition stage in the SLM process [52].

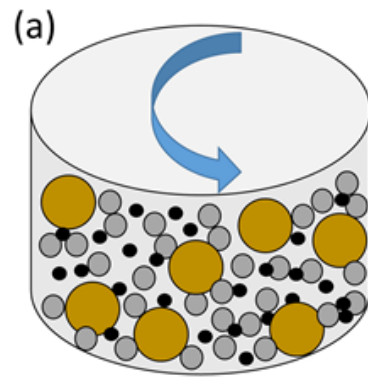

Ball milling process (b)

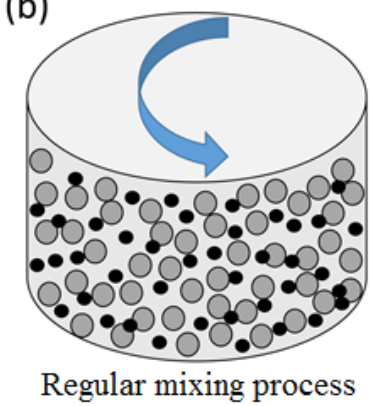

Ball

OMetallic

- Reinforcing

Particle

Figure 3. Schematic of: (a) ball milling and (b) regular mixing processes as the mechanical methods of producing composite powder for the SLM process [52].

\subsubsection{Requirements of an Ideal Composite Powder}

Despite the regular mixing process, which is free of metallic balls, the tremendous energy delivered to the powder particles by balls in the ball milling process leads to the fragmentation of brittle powder particles and induction of severe plastic deformation or even fragmentation of ductile materials [59]. Accordingly, ball milling process parameters need to be considered as essential factors governing the characteristics of the mixed powder system. The size, shape, and dispersion pattern of powder particles are the major characteristics of composite powder systems that affect the quality of SLM-fabricated parts [52]. To meet the requirements of SLM, the following items need to be considered in the composite powder preparation:

Minimizing the free reinforcing particles: The presence of reinforcing agent as free (non-attached to the metallic constituent) particles in the composite powder feedstock adversely affects the powder bed packing density and flowability. The adherence of reinforcing particles to the metallic powder is required to alleviate the chance of separation in the composite powder and, therefore, the microstructural heterogeneity in the final MMC part. Besides, the free reinforcing particles have a high tendency to form agglomerates to decrease their surface energy, leading to the poor dispersion state of reinforcements in the final microstructure.

Preserving the morphology of the metallic powder particles: Due to the high powder flowability, spherical powder particles are desired for SLM of monolithic materials [60,61]. Based on this well-accepted fact, the metallic constituent in the composite powder should maintain its spherical morphology to obtain the desired powder behaviors from the SLM viewpoint. Although the sphericity of metallic powder particles is almost guaranteed in the non-mechanical route as well as the regular mixing method, the severe plastic deformation and cold-welding of particles in the ball milling process lead to different levels of deviation from fully spherical shape depending on the applied process variables. This adversely affects the flowability of the composite powder $[52,62,63]$. Therefore, depending on the hardness, strength, and ductility of the metallic powder, appropriate mixing process parameters need to be employed to acquire composite powders with the desired morphology. 
Figure 4 provides the SEM micrograph of $5 \mathrm{wt} . \% \mathrm{~B}_{4} \mathrm{C} / \mathrm{Ti}-6 \mathrm{Al}-4 \mathrm{~V}$ composite powder system developed through the ball milling process. Although a slight deviation from fully spherical shapes is visible in a few particles due to the cold welding and deformation, the produced composite powder meets the requirements of the ideal powder for the SLM process [51].

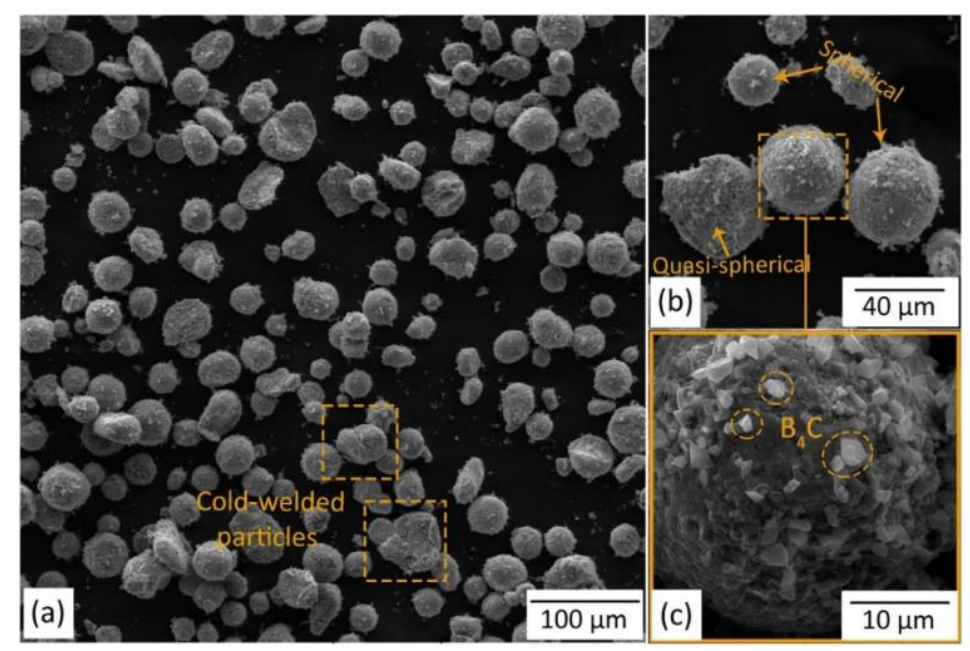

Figure 4. (a) SEM micrograph of the $5 \mathrm{wt} . \% \mathrm{~B}_{4} \mathrm{C} / \mathrm{Ti}-6 \mathrm{Al}-4 \mathrm{~V}$ composite powder obtained by $1.5 \mathrm{~h}$ of ball milling. (b) Higher magnification micrograph of (a). (c) Enclosed view of the selected region in (b) [51].

\section{Selection of Reinforcing Particles Based on the Potential Applications}

The second constituent in the MMCs can be in the form of (i) carbonaceous materials (carbon fiber, graphene, CNT), or (ii) ceramic particles $\left(\mathrm{SiC}, \mathrm{TiC}, \mathrm{TiB}\right.$, etc.)/ceramic precursors (e.g., $\mathrm{B}_{4} \mathrm{C}$ ). Chemical composition and type of the reinforcing particles incorporated into the metallic matrix are believed to dictate the functionality of the developed MMC. It should be borne in mind that these reinforcing particles can either remain unreacted (ex-situ composite) or experience complete (in-situ composite)/partial (hybrid ex-situ/in-situ composite) reaction with the matrix, which leads to the formation of in-situ synthesized reinforcements. Therefore, depending on the final reinforcements in the microstructure, the second constituent should be selected.

Table 2 summarizes the in-situ and hybrid ex-situ/in-situ reinforced AMCs and TMCs fabricated through the SLM process. The characteristics of the starting powder constituents, the composite powder fabrication method, as well as the micrograph of the developed composite powder and microstructure of the obtained MMCs, are also provided. In addition, the main outcomes of these research studies are highlighted, suggesting the improvement in the mechanical properties compared to the monolithic alloy systems. In the following, microstructural evolutions experienced by different families of reinforcing particles during the SLM process are elucidated. The dictated mechanical properties, which are of utmost importance in aerospace applications, are also provided in comparison to their non-reinforced systems. 
Table 2. Aluminum matrix composites (AMCs) and titanium matrix composites (TMCs) fabricated in recent years by SLM processing of composite powder feedstocks.

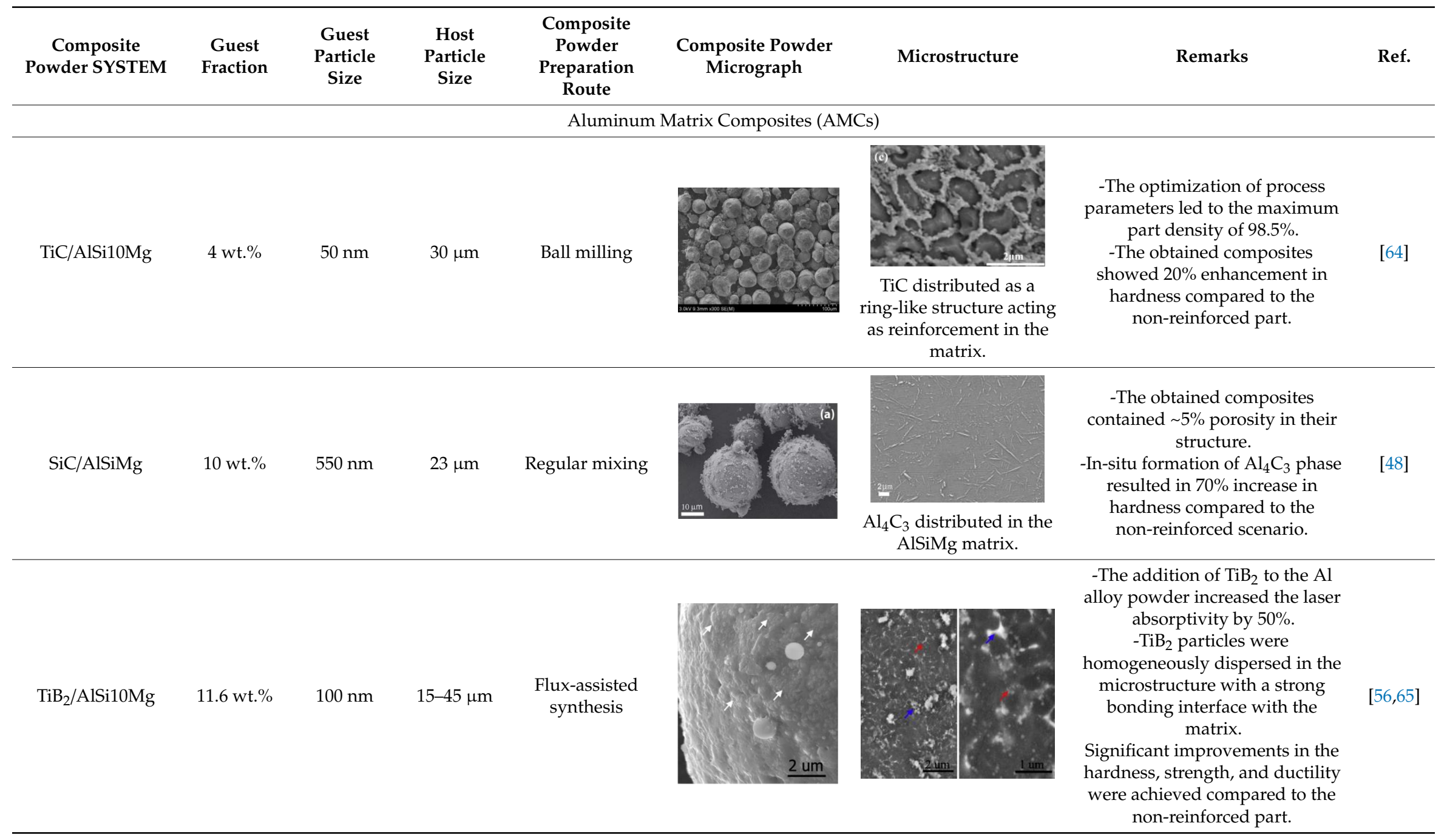


Table 2. Cont.

\begin{tabular}{|c|c|c|c|c|c|c|c|c|}
\hline $\begin{array}{c}\text { Composite } \\
\text { Powder SYSTEM }\end{array}$ & $\begin{array}{l}\text { Guest } \\
\text { Fraction }\end{array}$ & $\begin{array}{c}\text { Guest } \\
\text { Particle } \\
\text { Size }\end{array}$ & $\begin{array}{c}\text { Host } \\
\text { Particle } \\
\text { Size }\end{array}$ & $\begin{array}{c}\text { Composite } \\
\text { Powder } \\
\text { Preparation } \\
\text { Route }\end{array}$ & $\begin{array}{c}\text { Composite Powder } \\
\text { Micrograph }\end{array}$ & Microstructure & Remarks & Ref. \\
\hline $\mathrm{TiB}_{2} / \mathrm{Al}-3.5 \mathrm{Cu}-1.5 \mathrm{Mg}$ & $-15 \mathrm{~s}$ vol. $\%$ & $3 \mu \mathrm{m}$ & $41 \mu \mathrm{m}$ & Regular mixing & & & $\begin{array}{l}\text {-Incorporation of the } \mathrm{TiB}_{2} \\
\text { reinforcement significantly } \\
\text { decreased the grain size of the } \\
\text { matrix from } 23 \mu \mathrm{m} \text { in the } \\
\text { non-reinforced case to } 2.5 \mu \mathrm{m} \text {. } \\
\text {-The fabricated composite } \\
\text { showed } 20 \% \text { enhancement in } \\
\text { the yield strength than that of the } \\
\text { non-reinforced case. } \\
\text {-Heat treatment of the composites } \\
\text { was found to further improve the } \\
\text { mechanical properties. }\end{array}$ & [66] \\
\hline $\mathrm{TiC} / \mathrm{Al}$ & $\begin{array}{l}2.5 \text { and } 10 \\
\text { vol. } \%\end{array}$ & $\begin{array}{l}\text { Nano-scale } \\
\text { (the exact } \\
\text { size has } \\
\text { not been } \\
\text { noted) }\end{array}$ & $\begin{array}{l}11.3 \text { and } \\
5.9 \mu \mathrm{m}\end{array}$ & & & & $\begin{array}{l}\text {-The developed composite } \\
\text { powders showed noticeably } \\
\text { higher laser absorptivity than } \\
\text { that of pure Al. } \\
\text {-The fabricated composites had } \\
\text { significantly superior strength, } \\
\text { elastic modulus and thermal } \\
\text { stability compared to the } \\
\text { non-reinforced counterparts. } \\
\text {-The improved mechanical } \\
\text { properties were attributed to the } \\
\text { incorporation of well-dispersed } \\
\text { TiC particles, matrix grain } \\
\text { refinement, and strong } \\
\text { reinforcement/matrix interfacial } \\
\text { bonding. }\end{array}$ & [67] \\
\hline
\end{tabular}


Table 2. Cont.

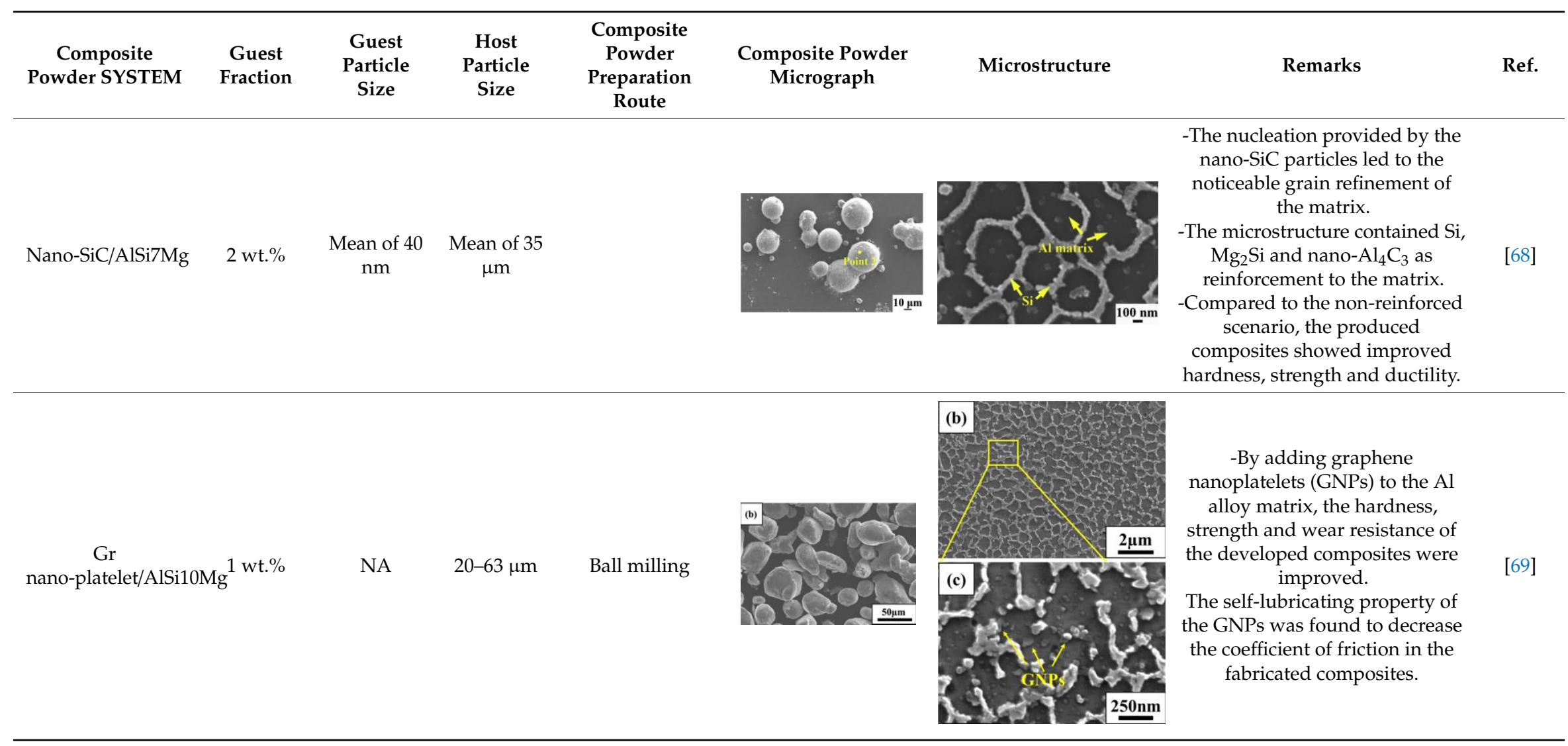


Table 2. Cont.

\begin{tabular}{|c|c|c|c|c|c|c|c|c|}
\hline $\begin{array}{c}\text { Composite } \\
\text { Powder SYSTEM }\end{array}$ & $\begin{array}{l}\text { Guest } \\
\text { Fraction }\end{array}$ & $\begin{array}{c}\text { Guest } \\
\text { Particle } \\
\text { Size }\end{array}$ & $\begin{array}{c}\text { Host } \\
\text { Particle } \\
\text { Size }\end{array}$ & $\begin{array}{l}\text { Composite } \\
\text { Powder } \\
\text { Preparation } \\
\text { Route }\end{array}$ & $\begin{array}{c}\text { Composite Powder } \\
\text { Micrograph }\end{array}$ & Microstructure & Remarks & Ref. \\
\hline $\begin{array}{l}\text { Micro-Submicron } \\
\text { TiC/AlSi10Mg }\end{array}$ & 15 wt. $\%$ & $\begin{array}{l}\text { Micron } \\
\text { scale(30-50 } \\
\mu \mathrm{m}) \text { Submicro } \\
\text { scale }(200 \\
\mathrm{nm}-2 \mu \mathrm{m})\end{array}$ & $\begin{array}{l}\text { Mean of } 42 \\
\mu \mathrm{m}\end{array}$ & Ball milling & NA & $\begin{array}{l}\quad i^{3} \\
\therefore i s\end{array}$ & $\begin{array}{l}\text { - 40\% increase in the laser } \\
\text { absorptivity and consequently } \\
\text { the improved processability } \\
\text { were achieved by adding TiC } \\
\text { constituent to the Al alloy } \\
\text { powder. } \\
\text {-The composites containing } \\
\text { micron-scale TiC were less } \\
\text { homogeneous and uniform in } \\
\text { terms of the dispersion of } \\
\text { reinforcing particles in the } \\
\text { microstructure. } \\
\text {-Densities as high as } 98 \% \text { were } \\
\text { obtained. } \\
\text {-Improvements in the hardness, } \\
\text { strength and wear resistance } \\
\text { were obtained through } \\
\text { composite fabrication. } \\
\text {-Composites containing } \\
\text { submicron TiC particles showed } \\
\text { superior strength and wear } \\
\text { resistance compared to those } \\
\text { having micron-scale TiC } \\
\text { particles. }\end{array}$ & [53] \\
\hline
\end{tabular}


Table 2. Cont.

\begin{tabular}{|c|c|c|c|c|c|c|c|c|}
\hline $\begin{array}{c}\text { Composite } \\
\text { Powder SYSTEM }\end{array}$ & $\begin{array}{c}\text { Guest } \\
\text { Fraction }\end{array}$ & $\begin{array}{c}\text { Guest } \\
\text { Particle } \\
\text { Size }\end{array}$ & $\begin{array}{c}\text { Host } \\
\text { Particle } \\
\text { Size }\end{array}$ & $\begin{array}{c}\text { Composite } \\
\text { Powder } \\
\text { Preparation } \\
\text { Route } \\
\end{array}$ & $\begin{array}{l}\text { Composite Powder } \\
\text { Micrograph }\end{array}$ & Microstructure & Remarks & Ref. \\
\hline CNT/AlSi10Mg & 1 wt. $\%$ & $\begin{array}{c}\text { Inner } \\
\text { diameter } \\
(5-10 \\
\text { nm)Outer } \\
\text { diameter } \\
(20-30 \\
\text { nm)Length } \\
(10-30 \mu \mathrm{m})\end{array}$ & NA & $\begin{array}{l}\text { Ultrasonication } \\
\text { followed by } \\
\text { drying }\end{array}$ & & $5 \mu \mathrm{m}$ & $\begin{array}{l}\text {-While still existing in the } \\
\text { microstructure, the laser and } \\
\text { thermal shocks subjected to the } \\
\text { carbon nanotubes (CNTs) led to } \\
\text { their decreased length. } \\
\text {-The portion of CNT which } \\
\text { reacted with the molten Al alloy } \\
\text { paved the way for the formation } \\
\text { of } \mathrm{Al}_{4} \mathrm{C}_{3} \text { phase. } \\
\text {-The fabricated composites were } \\
\text { accompanied by } \sim 10 \text { and } ~ 20 \% \\
\text { increase in the hardness and the } \\
\text { tensile strength compared to the } \\
\text { non-reinforced state. }\end{array}$ & [70] \\
\hline $\mathrm{Al}_{2} \mathrm{O}_{3} / \mathrm{Al}$ & 15 wt. $\%$ & $\begin{array}{l}\text { Mean of } \\
26.6 \mu \mathrm{m}\end{array}$ & $\begin{array}{c}\text { Mean of } 33 \\
\mu \mathrm{m}\end{array}$ & Ball milling & 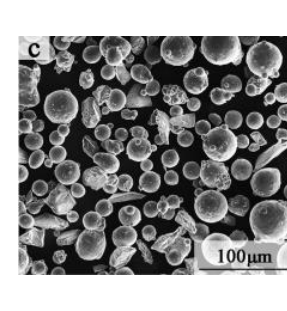 & 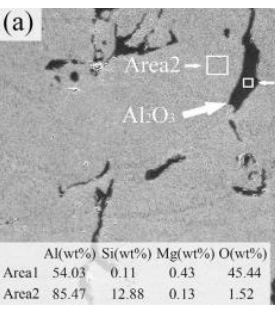 & $\begin{array}{l}\text {-The loss of } \mathrm{Al}_{2} \mathrm{O}_{3} \text { during SLM } \\
\text { processing was observed. } \\
\text {-The decrease in the scanning } \\
\text { speed and the hatch spacing led } \\
\text { to the elevated } \mathrm{Al}_{2} \mathrm{O}_{3} \text { loss. } \\
\text {-The main mechanism acting } \\
\text { behind the } \mathrm{Al}_{2} \mathrm{O}_{3} \text { loss was its } \\
\text { reduction reaction by the Al. }\end{array}$ & [71] \\
\hline
\end{tabular}


Table 2. Cont.

\begin{tabular}{|c|c|c|c|c|c|c|c|c|}
\hline $\begin{array}{c}\text { Composite } \\
\text { Powder SYSTEM }\end{array}$ & $\begin{array}{c}\text { Guest } \\
\text { Fraction }\end{array}$ & $\begin{array}{c}\text { Guest } \\
\text { Particle } \\
\text { Size }\end{array}$ & $\begin{array}{c}\text { Host } \\
\text { Particle } \\
\text { Size }\end{array}$ & $\begin{array}{l}\text { Composite } \\
\text { Powder } \\
\text { Preparation } \\
\text { Route }\end{array}$ & $\begin{array}{l}\text { Composite Powder } \\
\text { Micrograph }\end{array}$ & Microstructure & Remarks & Ref. \\
\hline $\mathrm{TiB}_{2} / \mathrm{AlSi} 10 \mathrm{Mg}$ & 3.4 vol. $\%$ & $<100 \mathrm{~nm}$ & $15-53 \mu \mathrm{m}$ & $\begin{array}{l}\text { Flux-assisted } \\
\text { synthesis }\end{array}$ & & & $\begin{array}{l}\text {-The fabricated nano-TiB } \\
\text { reinforced AlSi10Mg matrix } \\
\text { composites showed equiaxed } \\
\text { grains in the matrix with no } \\
\text { preferred crystallographic } \\
\text { texture. } \\
\text {-The composites exhibited } \\
\text { drastically higher strength and } \\
\text { ductility compared to the } \\
\text { non-reinforced AlSi10Mg case. } \\
\text { This was attributed to the } \\
\text { presence of nano-TiB }{ }_{2} \text { reinforcing } \\
\text { particles and their effects on the } \\
\text { grain refinement of the matrix. }\end{array}$ & [72] \\
\hline $\begin{array}{c}\mathrm{Al} \\
\text { coated-Gr/AlSi10Mg }\end{array}$ & $1 \mathrm{wt} . \%$ & NA & $15-50 \mu \mathrm{m}$ & $\begin{array}{l}\text { Organic } \mathrm{Al} \\
\text { reduction } \\
\text { method } \\
\text { followed by dry } \\
\text { ball milling }\end{array}$ & & Intmits & $\begin{array}{l}\text {-The graphene nano-platelets } \\
\text { were coated by Al to overcome } \\
\text { the wetting problems associated } \\
\text { with the interaction of solid } \\
\text { graphene platelets with the } \\
\text { molten Al during SLM. } \\
\text {-Although the graphene could } \\
\text { survive during the SLM process, } \\
\text { aluminum carbide was detected } \\
\text { in the microstructure. The finer } \\
\text { microstructure of the composite } \\
\text { was attributed to the ability of } \\
\text { graphene-coated particles to act } \\
\text { as nucleation sites for the } \\
\text { solidification of the matrix. } \\
\text {-Tensile strength and elongation } \\
\text { at break of composites increased } \\
\text { by } 11 \% \text { and } 13 \% \text {, respectively, } \\
\text { compared to the SLMed } \\
\text { AlSi10Mg alloy. }\end{array}$ & [73] \\
\hline
\end{tabular}


Table 2. Cont.

\begin{tabular}{|c|c|c|c|c|c|c|c|c|}
\hline $\begin{array}{c}\text { Composite } \\
\text { Powder SYSTEM }\end{array}$ & $\begin{array}{c}\text { Guest } \\
\text { Fraction }\end{array}$ & $\begin{array}{c}\text { Guest } \\
\text { Particle } \\
\text { Size }\end{array}$ & $\begin{array}{c}\text { Host } \\
\text { Particle } \\
\text { Size }\end{array}$ & $\begin{array}{l}\text { Composite } \\
\text { Powder } \\
\text { Preparation } \\
\text { Route }\end{array}$ & $\begin{array}{l}\text { Composite Powder } \\
\text { Micrograph }\end{array}$ & Microstructure & Remarks & Ref. \\
\hline & & & & & & & $\begin{array}{l}\text {-The wear resistance and } \\
\text { hardness of the composites } \\
\text { showed } 70 \% \text { and } 40 \% \\
\text { improvement, respectively } \\
\text { compared to the non-reinforced } \\
\text { condition. }\end{array}$ & \\
\hline SiC/AlSi10Mg & 15 wt. $\%$ & $\begin{array}{l}\text { Mean of } \\
46.1 \mu \mathrm{m}\end{array}$ & $\begin{array}{l}\text { Mean of } \\
33.7 \mu \mathrm{m}\end{array}$ & Ball milling & 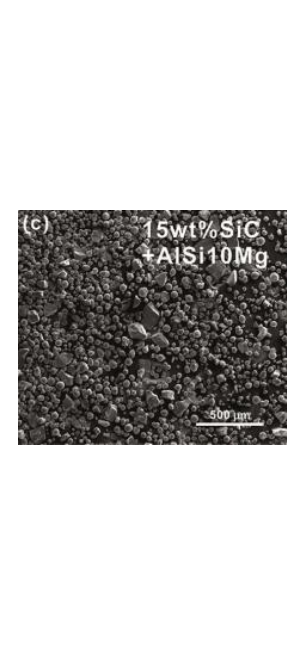 & 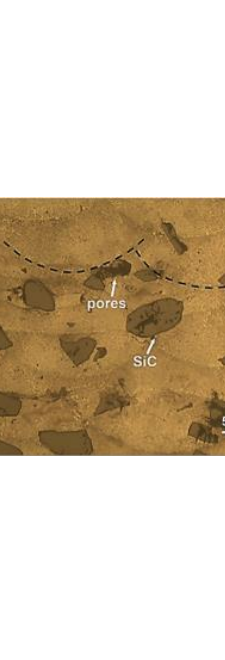 & $\begin{array}{l}\text {-Densities as high as } 97.7 \% \text { were } \\
\text { achieved. } \\
\text {-The } \mathrm{SiC} \text { particles partially react } \\
\text { with the surrounding melt at } \\
\text { their interfaces to form } \\
\text { needle-shape } \mathrm{Al}_{4} \mathrm{SiC}_{4} \text { phase. } \\
\text {-The highest hardness was } \\
\text { reported for parts with the } \\
\text { lowest porosity level. } \\
\text {-The fabricated composites } \\
\text { showed higher hardness but } \\
\text { lower strength than the } \\
\text { non-reinforced AlSi10Mg. This } \\
\text { was ascribed to the premature } \\
\text { failure caused by the crack } \\
\text { nucleation from the porosities } \\
\text { and large-sized SiC particles in } \\
\text { the composite structure. }\end{array}$ & [74] \\
\hline TiB2/Al12Si & 2 wt. $\%$ & $3.5-6 \mu \mathrm{m}$ & $20-60 \mu \mathrm{m}$ & Ball milling & NA & si precipitates & $\begin{array}{l}-\mathrm{TiB}_{2} \text { particles were } \\
\text { homogeneously dispersed in the } \\
\text { matrix. } \\
\text {-Compared to the hot-pressed } \\
\text { composite of the same system, } \\
\text { the SLM-fabricated composites } \\
\text { had finer matrix grain size as } \\
\text { well as higher hardness and } \\
\text { strength. }\end{array}$ & [75] \\
\hline
\end{tabular}


Table 2. Cont.

\begin{tabular}{|c|c|c|c|c|c|c|c|c|}
\hline $\begin{array}{c}\text { Composite } \\
\text { Powder SYSTEM }\end{array}$ & $\begin{array}{l}\text { Guest } \\
\text { Fraction }\end{array}$ & $\begin{array}{c}\text { Guest } \\
\text { Particle } \\
\text { Size }\end{array}$ & $\begin{array}{c}\text { Host } \\
\text { Particle } \\
\text { Size }\end{array}$ & $\begin{array}{c}\text { Composite } \\
\text { Powder } \\
\text { Preparation } \\
\text { Route }\end{array}$ & $\begin{array}{c}\text { Composite Powder } \\
\text { Micrograph }\end{array}$ & Microstructure & Remarks & Ref. \\
\hline \multicolumn{9}{|c|}{ Titanium Matrix Composites (TMCs) } \\
\hline $\mathrm{TiB}_{2} / \mathrm{CP}-\mathrm{Ti}$ & 5 wt. $\%$ & $3.5-6 \mu \mathrm{m}$ & 49 & Ball milling & & & $\begin{array}{l}\text {-Compared to the non-reinforced } \\
\text { counterparts, improvement in } \\
\text { the hardness and strength and } \\
\text { decrease in the flow stress and } \\
\text { ductility were achieved for } \\
\text { composites. This was attributed } \\
\text { to the strengthening effects of the } \\
\text { in-situ synthesized TiB phase } \\
\text { and the matrix grain refinement. }\end{array}$ & {$[76,77]$} \\
\hline $\mathrm{TiC} / \mathrm{CP}-\mathrm{Ti}$ & 15 wt. $\%$ & $50 \mathrm{~nm}$ & 22.5 & $\begin{array}{c}\text { Flux-assisted } \\
\text { synthesis }\end{array}$ & Hew & and & $\begin{array}{c}\text {-The added TiC powder particles } \\
\text { reacted with the Ti melt during } \\
\text { SLM processing and resulted in } \\
\text { the formation of in-situ } \\
\text { synthesized TiC phase as the } \\
\text { reinforcement. } \\
\text {-The morphology of TiC phase } \\
\text { was found to be dependent on } \\
\text { the employed laser energy } \\
\text { density. } \\
\text {-Significant improvements in the } \\
\text { hardness, elastic modulus and } \\
\text { wear resistance were reported for } \\
\text { the developed composites } \\
\text { compared to the non-reinforced } \\
\text { state. }\end{array}$ & [78] \\
\hline
\end{tabular}


Table 2. Cont.

\begin{tabular}{|c|c|c|c|c|c|c|c|c|}
\hline $\begin{array}{c}\text { Composite } \\
\text { Powder SYSTEM }\end{array}$ & $\begin{array}{l}\text { Guest } \\
\text { Fraction }\end{array}$ & $\begin{array}{c}\text { Guest } \\
\text { Particle } \\
\text { Size }\end{array}$ & $\begin{array}{c}\text { Host } \\
\text { Particle } \\
\text { Size }\end{array}$ & $\begin{array}{c}\text { Composite } \\
\text { Powder } \\
\text { Preparation } \\
\text { Route }\end{array}$ & $\begin{array}{c}\text { Composite Powder } \\
\text { Micrograph }\end{array}$ & Microstructure & Remarks & Ref. \\
\hline $\mathrm{B}_{4} \mathrm{C} / \mathrm{Ti}-6 \mathrm{Al}-4 \mathrm{~V}$ & $0.5,1$ wt. $\%$ & $2-3 \mu \mathrm{m}$ & $\begin{array}{l}\text { Mean size } \\
\text { of } 30 \mu \mathrm{m}\end{array}$ & Ball milling & & & $\begin{array}{c}\text {-Densification levels as high as } \\
99.3 \% \text { were achieved. } \\
\text {-The developed composites } \\
\text { showed significant improvement } \\
\text { in the hardness (micro- and } \\
\text { nano-) and compressive strength } \\
\text { compared to the non-reinforced } \\
\text { condition. } \\
\text {-The fracture mode was found to } \\
\text { be a mixture of ductile and } \\
\text { brittle. }\end{array}$ & [79] \\
\hline $\mathrm{ZRO} 2 / \mathrm{Ti}$ & $3 w t . \%$ & $\begin{array}{l}\text { Mean of } \\
270 \mathrm{~nm}\end{array}$ & $\begin{array}{c}\text { Mean of } 30 \\
\mu \mathrm{m}\end{array}$ & Ball milling & & & $\begin{array}{l}-\mathrm{ZrO}_{2} \text { particles were } \\
\text { homogeneously dispersed in the } \\
\text { matrix. } \\
\text {-Combination of grain refinement } \\
\text { strengthening and dispersion } \\
\text { strengthening mechanisms in the } \\
\text { developed composites led to a } \\
\text { hardness twice that of the } \\
\text { non-reinforced Ti. } \\
\text {-The wear resistance of } \\
\text { composites was significantly } \\
\text { higher than that of pure Ti due to } \\
\text { the dispersion strengthening and } \\
\text { formation of a strain hardened } \\
\text { tribolayer during sliding. }\end{array}$ & [80] \\
\hline
\end{tabular}


Table 2. Cont.

\begin{tabular}{|c|c|c|c|c|c|c|c|c|}
\hline $\begin{array}{c}\text { Composite } \\
\text { Powder SYSTEM }\end{array}$ & $\begin{array}{c}\text { Guest } \\
\text { Fraction }\end{array}$ & $\begin{array}{c}\text { Guest } \\
\text { Particle } \\
\text { Size }\end{array}$ & $\begin{array}{c}\text { Host } \\
\text { Particle } \\
\text { Size }\end{array}$ & $\begin{array}{l}\text { Composite } \\
\text { Powder } \\
\text { Preparation } \\
\text { Route }\end{array}$ & $\begin{array}{c}\text { Composite Powder } \\
\text { Micrograph }\end{array}$ & Microstructure & Remarks & Ref. \\
\hline $\mathrm{CrB} 2 / \mathrm{Ti}$ & $2 \mathrm{wt} . \%$ & $\begin{array}{c}-38+11 \\
\mu \mathrm{m}\end{array}$ & $\begin{array}{c}-81+25 \\
\mu \mathrm{m}\end{array}$ & Regular mixing & NA & & $\begin{array}{l}\text {-Due to the formation of in-situ } \\
\text { TiB and partial transformation of } \\
\text { the matrix to } \alpha \text { phase, the } \\
\text { developed composites showed } \\
\text { higher hardness and wear } \\
\text { resistance compared to the } \\
\text { non-reinforced state. }\end{array}$ & [81] \\
\hline $\mathrm{B}_{4} \mathrm{C} / \mathrm{Ti}-6 \mathrm{Al}-4 \mathrm{~V}$ & $5 \mathrm{wt} . \%$ & $1-3 \mu \mathrm{m}$ & $15-45 \mu \mathrm{m}$ & Ball milling & $\begin{array}{l}\text { Quas } \\
\text { (b) }\end{array}$ & 5,0 & $\begin{array}{l}\text {-The composite powder meeting } \\
\text { the requirements of the SLM } \\
\text { process was introduced. } \\
\text {-Higher laser energy densities led } \\
\text { to the enhanced in-situ reactions } \\
\text { between the reinforcing particles } \\
\text { and the surrounding melt. } \\
\text {-The SLM process led to a } \\
\text { microstructure extremely finer } \\
\text { than the arc-melted one. The } \\
\text { microstructure evolution was } \\
\text { also found to be non-equilibrium. } \\
\text {-Depending on the employed } \\
\text { laser energy density, 30-80\% } \\
\text { improvement in hardness was } \\
\text { achieved compared to the } \\
\text { non-reinforced scenario. }\end{array}$ & [51] \\
\hline
\end{tabular}


Table 2. Cont.

\begin{tabular}{|c|c|c|c|c|c|c|c|c|}
\hline $\begin{array}{c}\text { Composite } \\
\text { Powder SYSTEM }\end{array}$ & $\begin{array}{l}\text { Guest } \\
\text { Fraction }\end{array}$ & $\begin{array}{c}\text { Guest } \\
\text { Particle } \\
\text { Size }\end{array}$ & $\begin{array}{c}\text { Host } \\
\text { Particle } \\
\text { Size }\end{array}$ & $\begin{array}{c}\text { Composite } \\
\text { Powder } \\
\text { Preparation } \\
\text { Route } \\
\end{array}$ & $\begin{array}{l}\text { Composite Powder } \\
\text { Micrograph }\end{array}$ & Microstructure & Remarks & Ref. \\
\hline CNT/Ti-6Al-4V & 0.8 vol. $\%$ & NA & $15-53 \mu \mathrm{m}$ & $\begin{array}{l}\text { Chemical } \\
\text { vapour } \\
\text { deposition } \\
\text { (CVD) }\end{array}$ & & C nanopa & $\begin{array}{c}\text {-A novel technique was } \\
\text { introduced to produce } \\
\text { high-quality composite powders } \\
\text { for SLM applications. } \\
\text {-The relatively lower reactivity of } \\
\text { CNTs with Ti in the fabricated } \\
\text { composite powder system was } \\
\text { found to provide higher amounts } \\
\text { of non-reacted CNTs in the final } \\
\text { TMC structure. } \\
\text {-Compared to the TMCs with the } \\
\text { same or slightly higher TiC } \\
\text { contents, superior mechanical } \\
\text { properties were achieved. }\end{array}$ & [82] \\
\hline
\end{tabular}




\subsection{Carbonaceous Materials}

The incorporation of carbonaceous particles into a metallic matrix should not only lead to increased mechanical properties but also has the potential to improve thermal and electrical conductivity. Since the density of carbon is considerably lower than most of the metallic materials, the addition of carbonaceous particles can enhance the strength-to-weight ratio. On the other hand, the presence of carbonaceous materials can increase the damping capacity, which is essential in the aerospace and automotive industries. By increasing the hardness and at the same time reducing the coefficient of friction (COF) (due to the self-lubricating feature), incorporation of carbonaceous materials can noticeably decrease the wear rate. Besides, it has been reported in the literature that the addition of graphene nanosheets and CNTs increases not only the strength-to-weight ratio but also the ductility of the composite. It is believed that these improvements are unique to carbonaceous reinforcing particles over others. Nevertheless, microstructural investigations of the SLMed graphene/Al and CNT/Al composite systems have confirmed the formation of aluminum carbide within the matrix, suggesting that these reinforcing particles are not able to fully survive during the SLM process $[73,83,84]$.

\subsubsection{Surface Quality}

Figure 5 shows the effect of scanning speed, as one of the most critical SLM process parameters, on the melt pool dimension and surface quality of SLM-processed CNT/AlSi10Mg composite powder. By affecting the height and width of the tracks, the scanning speed plays a significant role in the surface quality of the fabricated parts. The lowest surface roughness $\left(S_{a} \approx 7 \mu \mathrm{m}\right)$ is achieved at an optimum scanning speed [70]. The effect of other process variables (i.e., laser power, hatch spacing and powder layer thickness) on the quality of the fabricated composite should follow the same trend. Therefore, the overall change in melt pool temperature, cooling rate, and convectional flows within the melt pool due to the addition of CNTs seems not to encourage the enhancement of surface roughness during the SLM process.
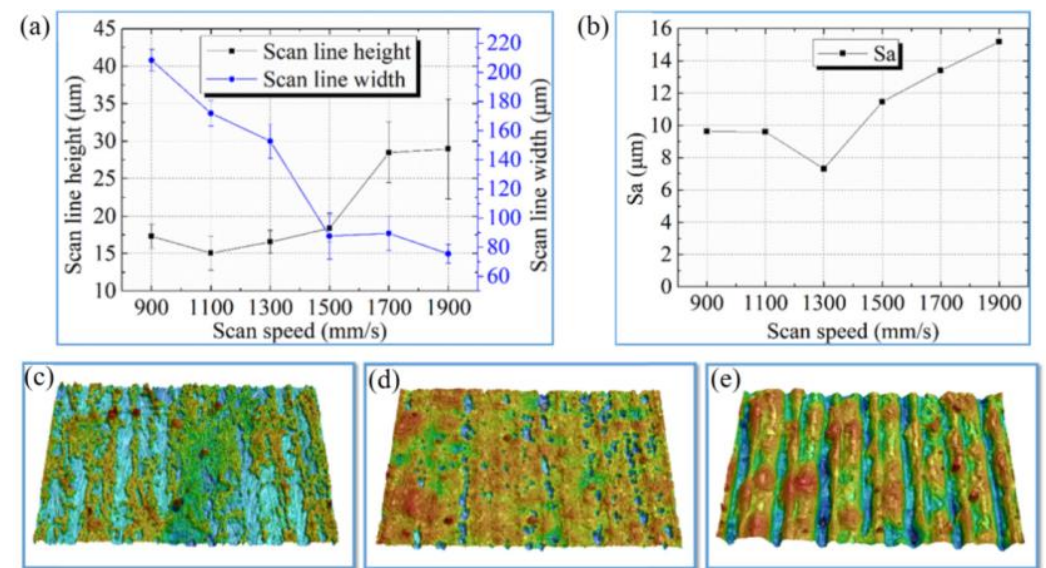

Figure 5. The variation in (a) scan line dimension, (b) the roughness of scan layers, and (c) the morphology of scan layers of SLM-processed $1 \mathrm{wt}$ \% carbon nanotubes (CNT)/AlSi10Mg composite powder as a function of the scanning speed. The micrographs provided in (c), (d), and (e) refer to the parts subjected to the scanning speed of 900,1300 , and 1700 , respectively [70].

\subsubsection{Densification Level}

One of the most common defects found in the AM-processed metals and MMCs is porosity. By acting as stress concentration sites and reducing the effective load-bearing area, these porosities adversely affect the mechanical properties, including strength, creep performance, and fatigue life [85-87]. Therefore, they need to be minimized or eliminated to improve the functionality and mechanical properties of the additively manufactured components. Figure 6 shows the level of 
porosities in non-reinforced and reinforced AlSi10Mg with graphene nanoplatelets (GNPs) fabricated with the same process parameters.

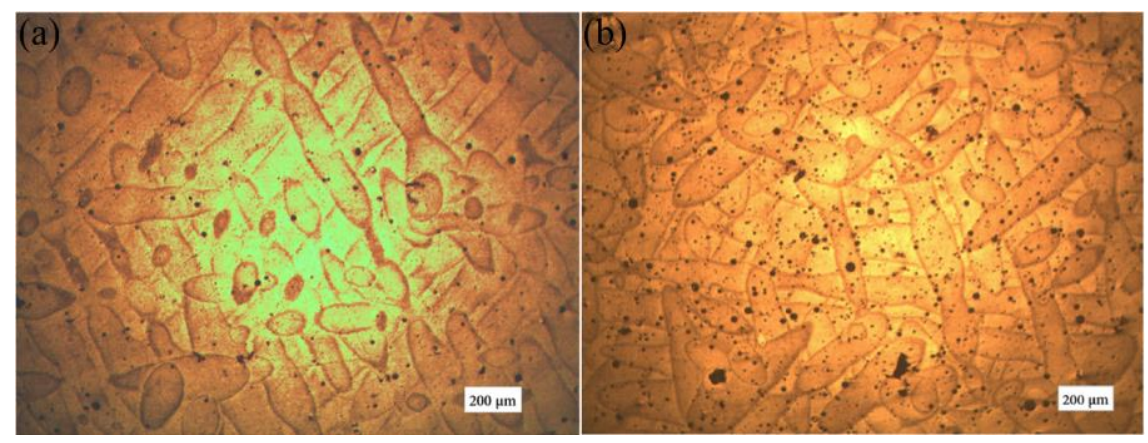

Figure 6. Optical micrographs of (a) AlSi10Mg, and (b) 0.5 wt.\% graphene nanoplatelets (GNP)/AlSi10Mg parts in as-built condition [88].

As is evident, the incorporation of GNPs resulted in the significant increase in the size and volume fraction of porosities which in turn offsets the improvement in mechanical properties. The decreased densification level is attributed to the entrapped gas and contaminations within the GNPs (spherical pores), insufficient wetting of GNPs by molten aluminum alloy and incomplete melting of the composite powder (irregular pores) [83,88]. It is worth noting that applied process parameters in the discussed research study were not optimized and denser GNP/Al alloy composites are processable through SLM techniques. Nevertheless, from the densification level point of view, addition of carbonaceous materials to the metallic matrices seems to be challenging. Optimization of process parameters and post processing treatments such as HIP may be required to further reduce the porosities and make them applicable for the aerospace industry.

\subsection{Ceramic Particles/Ceramic Precursors}

Lightweight MMCs which benefit from extraordinary wear resistance (due to the hardness enhancement), improved compressive strength, and excellent high-temperature stability (i.e., creep resistance) can be fabricated by addition of either ceramic particles or ceramic precursors. Relatively large-size ceramic particles remain undissolved during the thermal cycle of the SLM process. $\mathrm{SiC}$ reinforced AMCs fabricated by the SLM process are among a few systems that could be considered as ex-situ reinforced MMCs (specifically when SiC particles are noticeably coarse). The bonding coherence between the reinforcing particles and the Al-based matrix is one of the crucial factors in such MMCs governing the mechanical and functional properties of manufactured AMCs. While SiC particles usually tend to form a good bonding with the Al matrix (Figure 7a), the extremely fast cooling rates associated with the SLM process as well as the difference between the coefficient of thermal expansions (CTEs) of $\mathrm{SiC}$ and the $\mathrm{Al}$ matrix may lead to the generation of cracks at reinforcement/matrix interfaces (Figure $\mathrm{7b}$ ). These cracks degrade the interfacial bonding coherence and, consequently, the mechanical properties [89].

However, fine ceramic particles experience partial/complete dissolution and then re-precipitate through in-situ reactions. The in-situ synthesized reinforcement(s) may be the same as or different from the starting reinforcing particle depending on the metallic matrix chemical composition. For instance, SLM processing of the TiC/Al composite powder system results in the formation of the same TiC phase as the product of the in-situ reaction through solution precipitation mechanism, meaning that the primarily added $\mathrm{TiC}$ particles dissolved into the $\mathrm{Al}$ matrix re-precipitate in the matrix by heterogeneous nucleation followed by growth (Figure 8a). This can be confirmed by comparing the size and morphology of the TiC phase in the SLM-processed AMCs with the particulate morphology of TiC particles in the starting composite powder [67]. However, full reaction of nano-SiC particles with the surrounding $\mathrm{Al}$ during SLM processing leads to the formation of a different phase $\left(\mathrm{Al}_{4} \mathrm{C}_{3}\right)$ 
(Figure 8b) [68]. As an example of TMCs, the dissolution of irregular-shape $\mathrm{B}_{4} \mathrm{C}$ particles in the Ti melt during SLM process results in the formation of two new phases of TiB and TiC (Figure 8c).

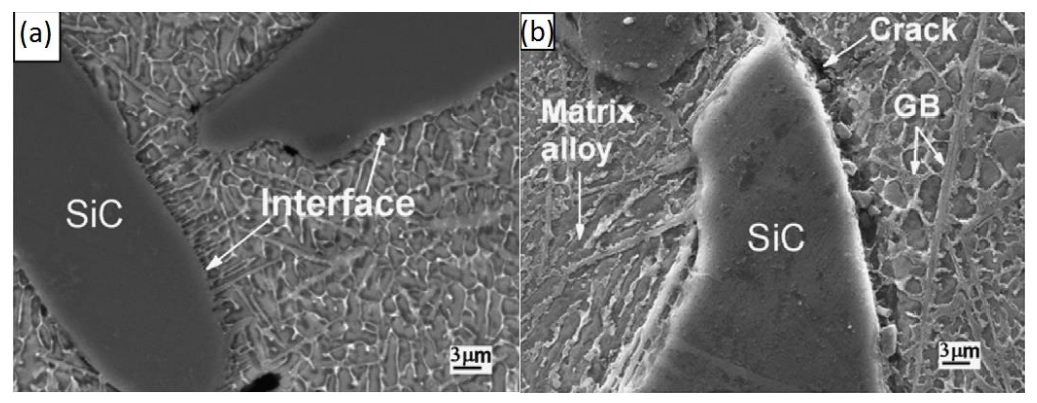

Figure 7. SEM images of the interface between $\mathrm{SiC}$ reinforcing particles and the $\mathrm{Al}-4.5 \mathrm{Cu}-3 \mathrm{Mg}$ matrix in AMCs fabricated through the direct metal laser sintering (DMLS) process showing (a) matrix/reinforcement bonding interface, and (b) formation of micro-cracks in the interfacial region [89].

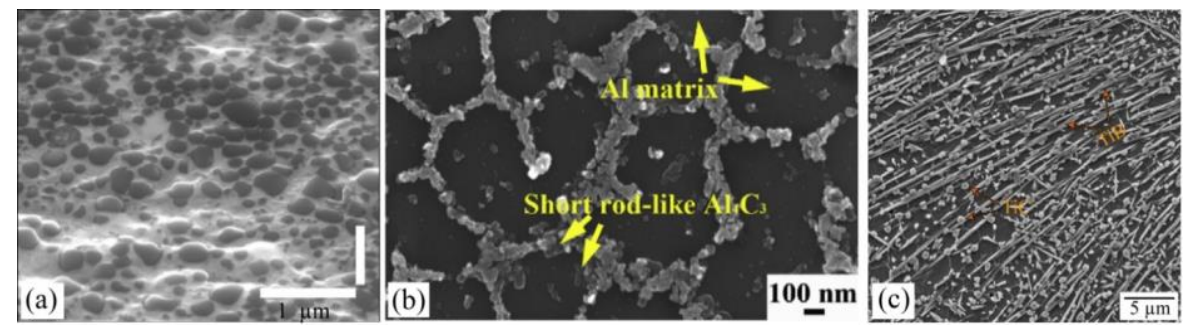

Figure 8. SEM micrographs of SLM-processed: (a) 35 vol.\% TiC/Al [67], (b) 2 wt.\% nano-SiC/ AlSi7Mg [68] and (c) 5 wt. $\% B_{4} \mathrm{C} / \mathrm{Ti}-6 \mathrm{Al}-4 \mathrm{~V}$ (own work) composite powder systems. The particulateshape phase in (a) is $\mathrm{TiC}$, which is formed through the dissolution-precipitation mechanism. The full decomposition of $\mathrm{SiC}$ nanoparticles and the subsequent reaction of $\mathrm{C}$ atoms with the $\mathrm{Al}$ matrix results in the formation of in-situ synthesized short rod-like $\mathrm{Al}_{4} \mathrm{C}_{3}$ phase in (b). The reaction between the starting reinforcing particle and the surrounding Ti alloy melt during SLM processing leads to the in-situ synthesis of $\mathrm{TiB}$ and $\mathrm{TiC}$ phases with needle-like and particulate-shape morphologies, respectively, in (c).

To have multiple in-situ synthesized reinforcements in the final microstructure, fine ceramic precursors are incorporated into the metallic systems. The reaction of $\mathrm{B}_{4} \mathrm{C}$ particles with the Ti alloy melt during SLM processing of $\mathrm{B}_{4} \mathrm{C} / \mathrm{Ti}-6 \mathrm{Al}-4 \mathrm{~V}$ composite powder has been shown to result in the formation of two new phases ( $\mathrm{TiB}$ and $\mathrm{TiC}$ ) which are different from the starting reinforcing particle (Figure 8b) [51]. These phases can improve the wear resistance and creep durability of Ti alloy significantly. For high-temperature applications, the reinforcements need to have CTEs close to that of the metallic matrix to hinder reinforcement/matrix interfacial separation or cracking. It is worth noting that the addition of ceramic particles/ceramic precursors is usually accompanied by a considerable decrease in the ductility of the developed composite material $[51,79,80]$.

\subsubsection{Surface Quality}

During the SLM process, the laser beam linearly scans the powder bed. As a result, a molten region with a cylindrical shape is formed behind the laser spot. When it comes to metallic powders, the melt track may break down to spherical-shape agglomerates to reduce the surface energy. When the cylinder circumference $(\pi \mathrm{D})$, in which $\mathrm{D}$ is the diameter of the cylinder or agglomerates, is less than the sinusoidal fluctuations, the molten track tends to break [90]. This phenomenon is known as the "balling effect" and degrades the surface quality of additively manufactured parts [91]. The starting reinforcing particles incorporated into the composite powder as the second constituent can increase both $\mathrm{D}$ and the laser absorptivity. These factors act to reduce the probability of balling effect 
occurrence and result in the formation of more continuous surface morphology with a reduced size of inter-connected porosities, as seen in Figure 9 [92].
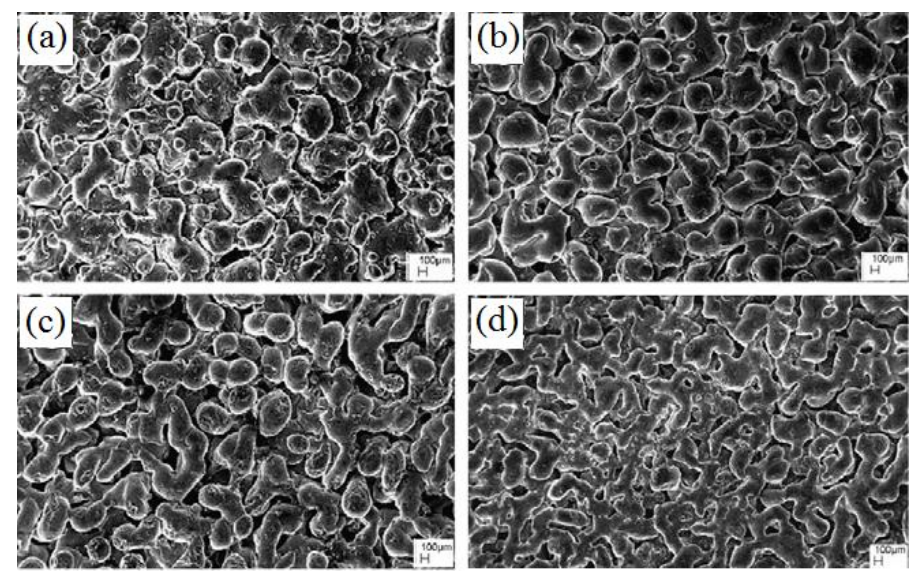

Figure 9. The surface morphology of (a) pure Al-7Si-0.3Mg as well as SiC-reinforced Al-7Si-0.3Mg matrix composites with (b) 5, (c) 10, and (d) 20 vol.\% SiC fabricated by the selective laser sintering (SLS) process [92].

It is worth noting that the increase in the volume fraction of reinforcing particles is not necessarily associated with the improved surface quality. The lower temperature and higher viscosity of melt induced in MMCs with relatively small contents of reinforcing particles limit the materials flow and lead to the formation of inter-connected porosities and relatively rough surfaces [93].

\subsubsection{Densification Level}

Several sources and mechanisms have been suggested for the formation of porosities in SLM-fabricated parts, including lack of fusion, un-melted/partially melted powder particles, keyhole effect, inter-track/inter-layer delamination as well as the entrapment of gas or alloy vapor inside the melt pool [30-32,87,94-99]. In addition to these mechanisms which are governed by the process parameters, the formation of defects in SLM-processed MMCs is affected by the characteristics of the powder feedstock. The following discusses the effects of powder characteristics on the densification level of the SLM-processed MMCs reinforced with ceramic particles.

Volume fraction of reinforcing particles: The densification of SLM-processed composites is believed to obey the first-order kinetic law (Equation (1)) [92,100]:

$$
\frac{\mathrm{d} \varepsilon}{\mathrm{dt}}=\mathrm{k} \varepsilon
$$

In which $\mathrm{k}, \varepsilon$, and $\mathrm{t}$ are the constant rate for densification, the total porosity, and time, respectively. Studies have shown that although the increase in the content of reinforcing particles up to a critical amount enhances the bed porosity, it elevates the densification rate of fabricated MMCs. Further increase in the reinforcement content beyond a critical value reduces the densification rate. The effect of reinforcement content on the densification level of SLM-fabricated MMCs could be discussed in terms of the following consequences: (i) the bed porosity, (ii) the capability of laser energy absorption, and (iii) the melt viscosity. The increase in reinforcing content enhances both the bed porosity and the melt viscosity. However, due to the higher laser absorption coefficient of ceramic reinforcing particles than those of metallic constituents, their addition may elevate the overall laser absorptivity of the composite powder system and consequently increase the melt pool temperature. While the enhanced laser absorptivity is the dominant factor at low contents of reinforcing particles, both the increased bed porosity and elevated melt viscosity are the governing roles when having relatively high amounts of reinforcing particles. It is also worth noting that high contents of reinforcing particles in the composite 
powder increase their agglomeration probability, which may reduce the overall effective surface area of particles and consequently decline the laser energy absorption [92]. Figure 10 shows the effect of $\mathrm{SiC}$ volume fraction on the densification rate of the $\mathrm{SiC} / \mathrm{Al}-7 \mathrm{Si}-0.3 \mathrm{Mg}$ system subjected to the direct metal laser sintering (DMLS) process. The densification level first increased and then decreased by enhancing the $\mathrm{SiC}$ content, leaving a peak at $5 \mathrm{vol} . \% \mathrm{SiC}$. Moreover, increasing of the $\mathrm{SiC}$ fraction in the range of 10-20 vol.\% slightly improved the densification rate, but led to lower sinterabilities compared to that of the non-reinforced $\mathrm{Al}$ alloy [92].

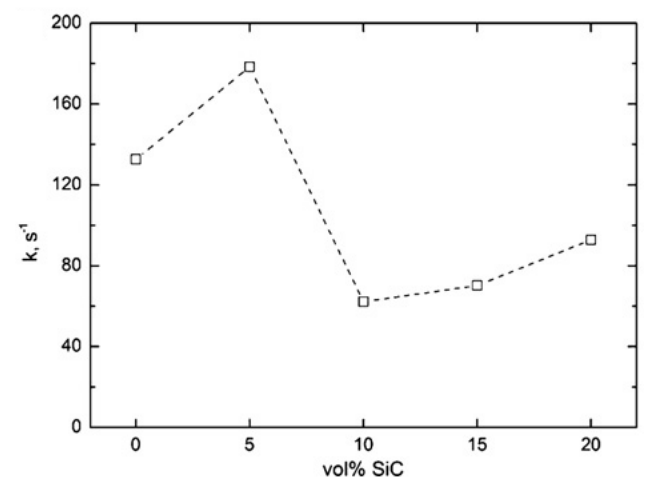

Figure 10. Variation of densification rate as a function of $\mathrm{SiC}$ volume fraction for DMLS-processed $\mathrm{SiC} / \mathrm{Al}-7 \mathrm{Si}-0.3 \mathrm{Mg}$ composite powder system [92].

Size of reinforcing particles: In addition to the volume fraction, the size of reinforcing particles also plays a vital role in the densification level of SLM-processed MMCs. The larger surface area of finer particles enhances the laser absorptivity of the composite powder system. This consequently elevates the melt pool temperature, reduces the melt viscosity, improves the reinforcement/matrix wettability and bonding coherence, and enhances the extent of in-situ reaction between reinforcing particles and the matrix. Therefore, MMCs with increased densification levels may be achieved, as shown in Figure 11 for an SLM-processed SiC/AlSi10Mg composite powder system. On the other hand, the increased possibility of particle clustering associated with finer reinforcing particles may adversely affect the density by (i) reducing the laser absorptivity, and (ii) increasing the melt pool viscosity. The overall outcome of two counterpart phenomena (i.e., higher laser absorptivity vs. higher clustering and increased melt viscosity) governs the effect of reinforcing particle size on the densification level of composites $[89,101]$.
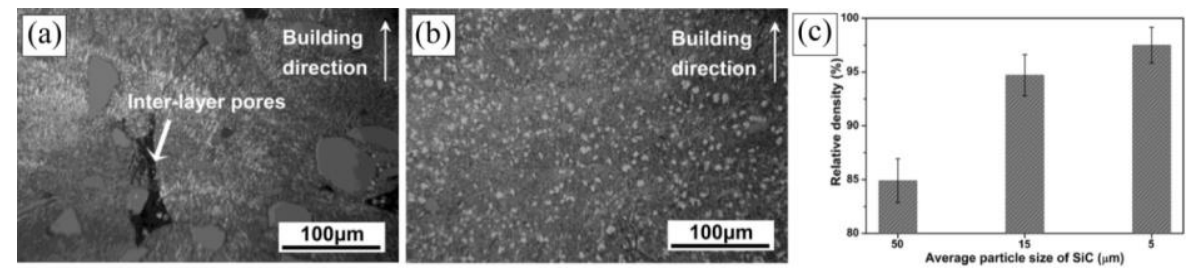

Figure 11. Cross-sectional optical micrographs of SLM-processed SiC/AlSi10Mg mixed powder system containing: (a) coarse and (b) fine starting $\mathrm{SiC}$ powder particles. (c) The change in relative density of parts as a function of $\mathrm{SiC}$ average particle size [102].

\section{Mechanical Properties-Monolithic Alloys vs. Composites}

\subsection{Hardness}

One of the primary purposes behind composite fabrication is the improvement in mechanical properties. Among various mechanical properties, the hardness of the SLM-processed MMCs has been analyzed in many research studies, as plotted in Figure 12. In most cases, the reinforcements are ceramic particles having noticeably higher hardness compared to the metallic matrix. As shown in 
Figure 12, incorporation of reinforcements into the metallic matrix leads to a higher hardness compared to the non-reinforced state due to the following reasons:

- When adding reinforcements to the system, a fraction of the metallic matrix is substituted by a harder constituent(s). Since the ceramic reinforcements typically have higher hardness than the metallic matrix, such a replacement leads to higher hardness based on the well-known mixture rule.

- The reinforcements incorporated into the metallic matrix, restrain its local micro-deformation by hindering the movement of dislocations [103]. Therefore, higher stresses are required for the deformation of the structure, resulting in higher hardness and strength.

- The solid reinforcing particles dispersed into the melt during laser processing act as heterogeneous nucleation sites for the matrix during its solidification [1,2]. This results in the grain refinement of the matrix and, consequently, the enhancement of hardness and strength $[68,72]$. The extent of such grain refinement is a major function of the size, volume fraction, and distribution pattern of reinforcing particles. The increase in volume fraction and decrease in size of reinforcing particles are regarded as the strategies providing the matrix with finer grains [89]. On the other hand, non-uniform matrix grain refinement induced by inhomogeneous distribution of reinforcements may degrade the mechanical properties of manufactured composites [48]. The composition of reinforcement is another factor that affects the hardness by influencing the formation of in-situ synthesized reinforcements and intermetallic phases during the process [104].

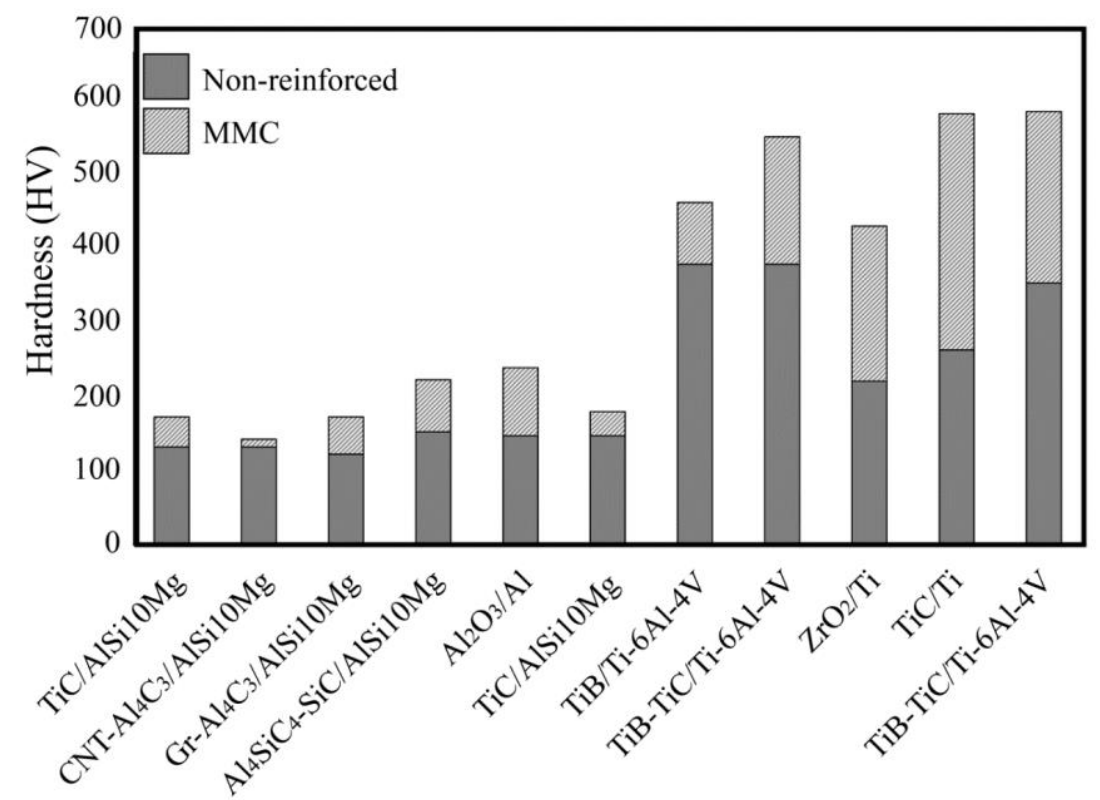

Figure 12. A comparison between the hardness of SLM-processed AMCs/TMCs and their monolithic non-reinforced counterparts in TiC/AlSi10Mg [53], CNT-Al $\mathrm{Cl}_{3} / \mathrm{AlSi10Mg}$ [70], Gr- $\mathrm{Al}_{4} \mathrm{C}_{3} / \mathrm{AlSi10Mg}$ [73], $\mathrm{Al}_{4} \mathrm{SiC}_{4}-\mathrm{SiC} / \mathrm{AlSi10Mg}$ [74], $\mathrm{Al}_{2} \mathrm{O}_{3} / \mathrm{Al}$ [105], TiC/AlSi10Mg [106], TiB/Ti-6Al-4V [79], TiB-TiC/ Ti-6Al-4V [79], $\mathrm{ZrO}_{2} / \mathrm{Ti}$ [80], TiC/Ti [107] and TiB-TiC/Ti-6Al-4V [51] systems. Microhardness measurements have been conducted on coupons with the same shape but different sizes.

\subsection{Tensile/Compressive Strength}

Since its emergence, SLM technology has led to the fabrication of parts with superior strength and acceptable ductility compared to those processed with conventional manufacturing methods [18]. Figure 13 compares the strength/ductility of SLM-processed AMCs/TMCs and their monolithic counterparts. While the incorporation of reinforcements into the metallic matrix provides the enhancement in strength (Figure 13a), it is generally associated with the decrease in ductility (Figure 13b). 
However, research studies have recently shown the enhancement in both strength and ductility in SLM-processed nano-composites (Figure 13).
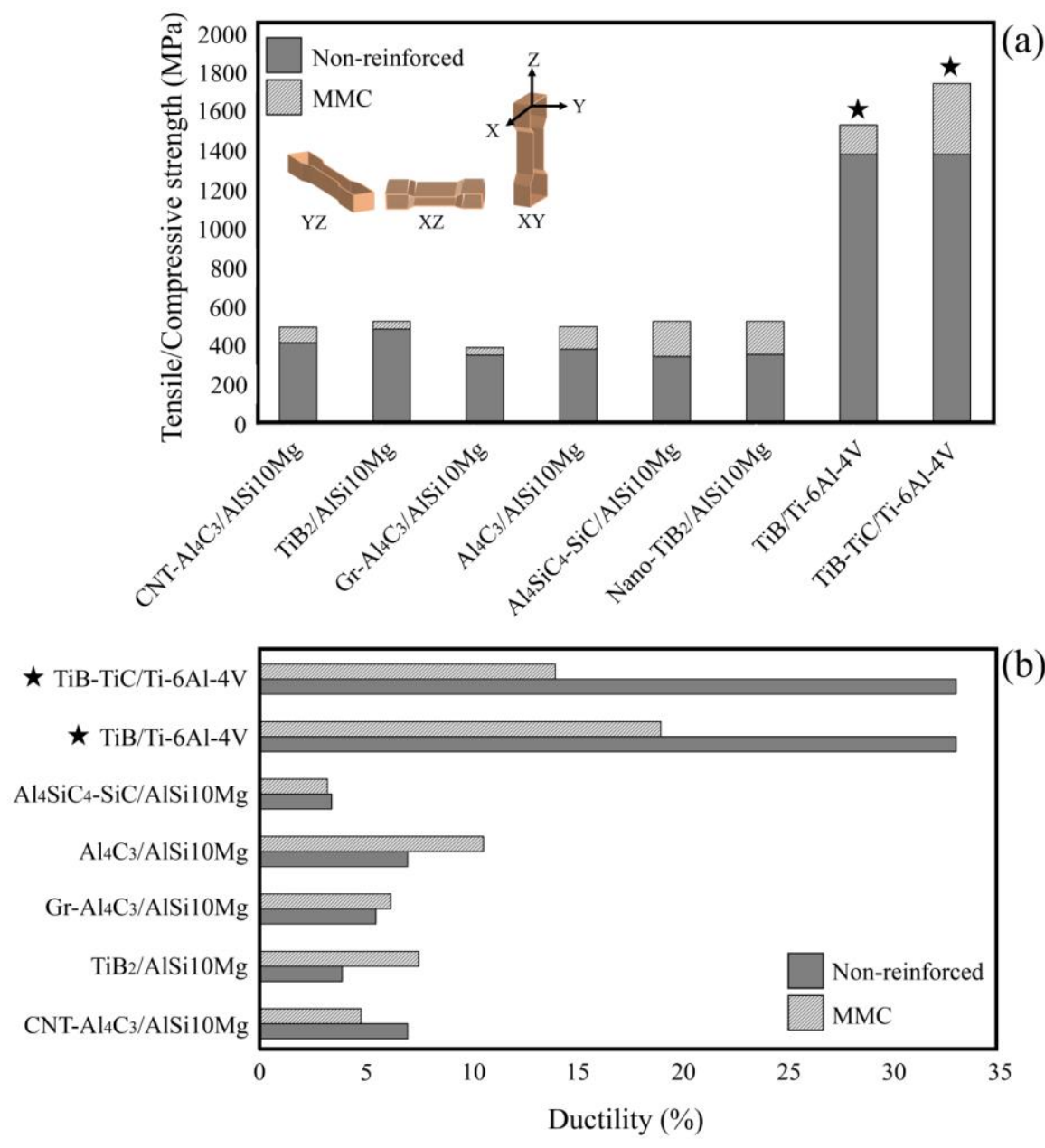

Figure 13. A comparison between (a) the tensile strength and compressive strength ${ }^{*}$ ), and (b) the ductility of the SLM-fabricated AMCs/TMCs and their monolithic alloys in CNT- $\mathrm{Al}_{4} \mathrm{C}_{3} / \mathrm{AlSi10Mg}$ [70], $\mathrm{TiB}_{2} / \mathrm{AlSi10Mg}$ [72], Gr- $\mathrm{Al}_{4} \mathrm{C}_{3} / \mathrm{AlSi10Mg}$ [73], $\mathrm{Al}_{4} \mathrm{C}_{3} / \mathrm{AlSi10Mg}$ [68], $\mathrm{Al}_{4} \mathrm{SiC}_{4}-\mathrm{SiC} / \mathrm{AlSi10Mg}$ [74], Nano-TiB $2 / A 1 S i 10 M g$ [56], TiB/Ti-6Al-4V [79] and TiB-TiC/Ti-6Al-4V [79] systems. The orientation of samples is as $\mathrm{YZ}$ in [70], $\mathrm{XZ}$ in [73], and $\mathrm{XY}$ in [79] and [72], as schematically shown in (a). Note: samples do not have the same dimensions.

The strengthening of MMCs is determined by the contribution of direct and indirect strengthening mechanisms. While the direct strengthening is concerned with the load transfer from the matrix to reinforcements, the indirect one refers to the matrix strengthening caused by the presence of reinforcements [2]. By acting as barriers to the movement of dislocations, the reinforcements incorporated into the matrix restrain its local micro-deformation and consequently improve the strength [103,108-110]. The amount of increment in the strength of discontinuously reinforced MMCs is influenced by some variables, including the type, size, shape, dispersion state, and volume fraction of reinforcements. Indirect strengthening mechanisms involved in SLM-processed MMCs could be described as follows:

- Matrix grain refinement: The rapid cooling rates associated with the SLM process lead to significant grain refinement [95]. In the case of MMCs, the reinforcements can further refine the microstructure of the matrix by acting as preferential nucleation sites and grain growth inhibitors [2]. Due to the significant role of grain boundaries on the movement of dislocations, the 
increased fraction of grain boundaries obtained by grain refinement elevates the plastic deformation resistivity and consequently improves the strength of the material [111]. The reinforcing particles can also reduce the anisotropy in microstructure and mechanical properties [112]. As shown in Figure 15, the $\mathrm{TiB}_{2}$ reinforcing particles have remarkably reduced the anisotropy in the microstructure and texture of $\mathrm{TiB}_{2} / \mathrm{AlSi} 10 \mathrm{Mg}$ composites. Compared to the relatively coarse columnar grain structure, strong $<100>$ fiber orientation texture and the anisotropy in the mechanical properties for the AlSi10Mg alloy, the nano- $\mathrm{TiB}_{2}$ reinforced AMCs have shown equiaxed grains, no preferred crystallographic texture and significantly reduced anisotropy in mechanical properties [72].

- Solid solution strengthening: Due to the non-equilibrium nature of the process, the solution limit of alloying elements into the matrix can be extended, which favors a solid solution strengthening mechanism [113]. Compared to the substitutional alloying elements, the larger size misfit provided by interstitial alloying elements can generate significantly stronger obstacles for the movement of dislocations, leading to higher levels of solid solution strengthening [114]. Solid solution strengthening mechanisms have been reported in several research studies related to AM of MMCs [115-120].

- Enhanced dislocation density: The dislocations generated in the SLM-processed parts have various resources, including multiple reheating thermal cycles caused by the layer-wise nature of this process as well as the difference between the CTE and elastic modulus of reinforcements and the matrix. Although the dislocations generated by repeated reheating cycles are evident in all AM processes, those induced by the mismatches in CTE and elastic modulus are features of composites [2]. To accommodate these mismatches, geometrically necessary dislocations are generated in the vicinity of the reinforcement/matrix interface (Figure 14a). The increase in the density of dislocations during the deformation of MMCs leads to higher work hardening rates and consequently results in improved strength (Figure 14b) [73].

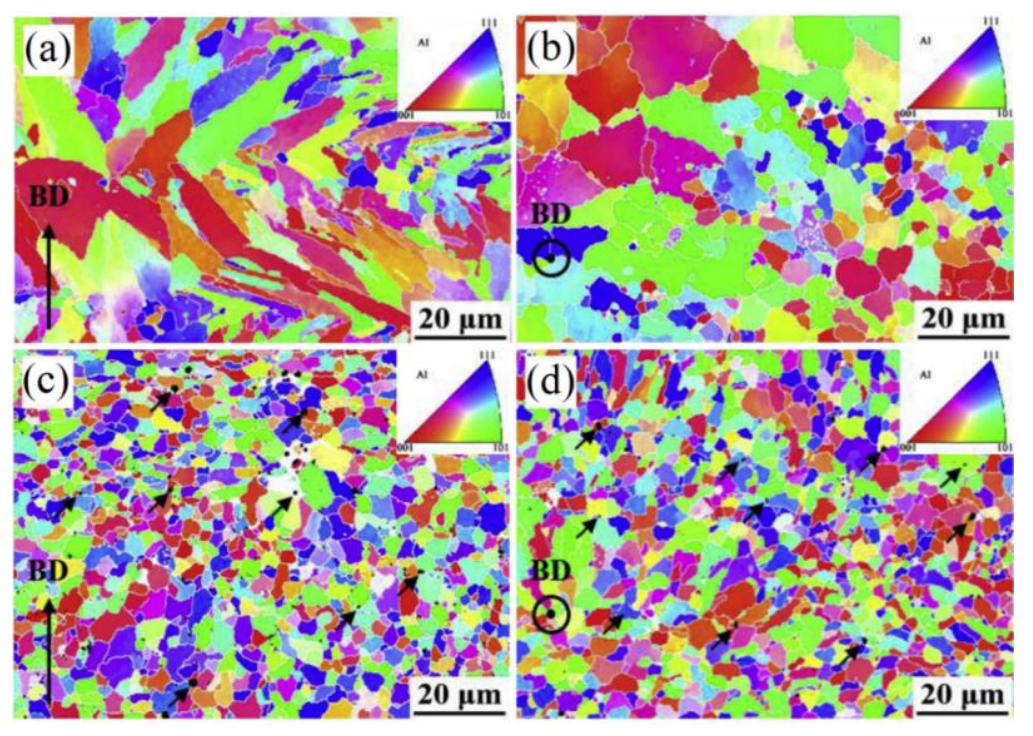

Figure 14. TEM images of SLM-processed Al-coated graphene/AlSi10Mg composite: (a) before and (b) after the deformation [73]. 


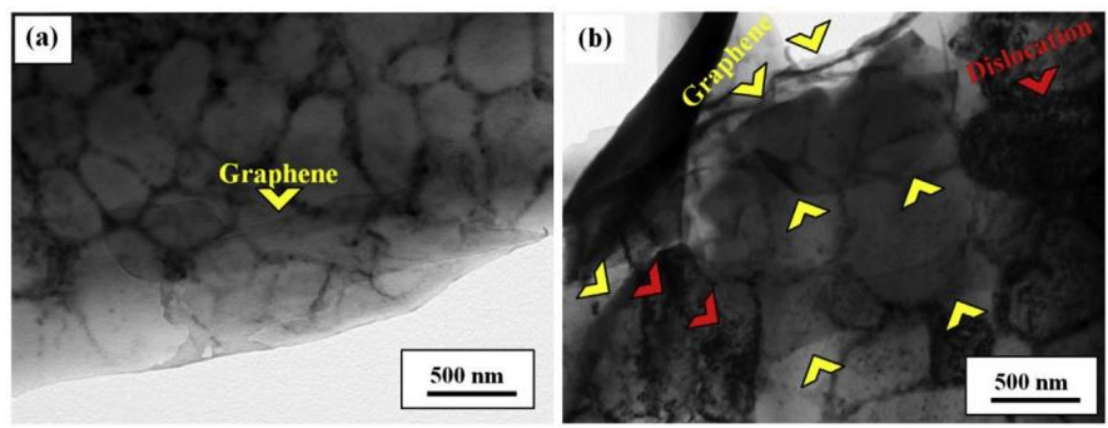

Figure 15. Electron backscattered diffraction (EBSD) inverse pole figure (IPF) maps of SLM-processed:

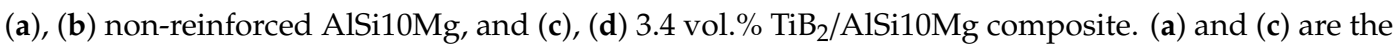
side-view while $(\mathbf{b})$ and $(\mathbf{d})$ are the top-view. The black arrows in $(\mathbf{d})$ and $(\mathbf{e})$ point to the $\mathrm{TiB}_{2}$ reinforcing particles [72].

Despite the beneficial effects of nano-sized reinforcing particles on hardness, strength, and ductility, the addition of relatively high amounts of large-sized reinforcing particles can deteriorate the mechanical properties. Figure 16 shows the fracture surface of SLM-processed $15 \mathrm{wt}$ \% SiC/AlSi10Mg composite powder in which the starting $\mathrm{SiC}$ particles had an average size of $\sim 46 \mu \mathrm{m}$. Although the developed AMCs were $47 \%$ harder than the non-reinforced counterpart, both the ultimate tensile strength and elongation to fracture were found to be significantly lower due to the premature failure initiated from the internal porosities and large-sized un-reacted $\mathrm{SiC}$ particles existing in the microstructure [74].

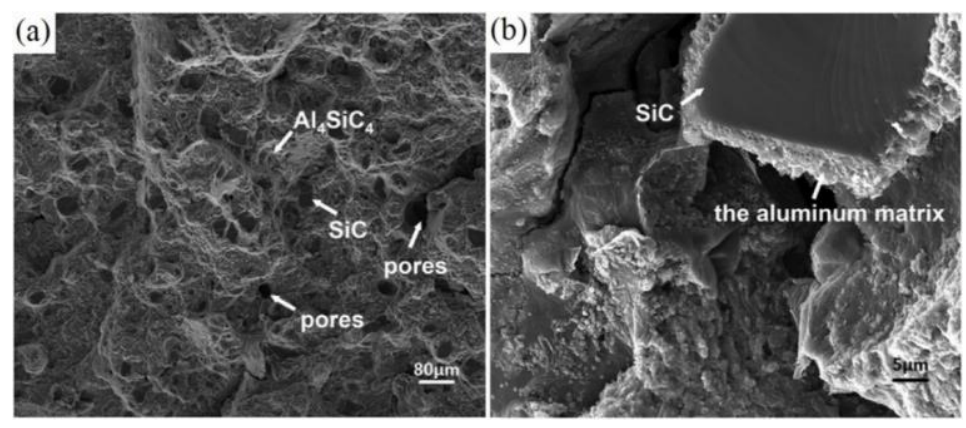

Figure 16. (a) and (b) Fracture surface of the SLM-processed 15 wt.\% SiC/AlSi10Mg composite system subjected to tensile testing showing un-reacted $\mathrm{SiC}$ particles and porosities [74].

\subsection{Wear Properties}

MMCs typically benefit from better wear resistance compared to non-reinforced counterparts [121]. The wear resistance of AM-fabricated components can be evaluated in both macro and nano scale. The pin-on-disk method and macro-scratching are the most frequently used techniques for macro-scale characterization of wear while nano-scratching performed by nano-indentation and atomic force microscopy (AFM) equipment are also employed for nano-scale analysis of wear. The wear properties of SLM-fabricated composites are affected by the type, size, and volume fraction of reinforcements. As shown in Figure 17, the SLM-processed TiC/AlSi10Mg composites are associated with the lower wear rate and coefficient of friction (COF) than the non-reinforced AlSi10Mg part. Additionally, the composites containing TiC particles with two different sizes show wear properties close to each other. However, some research studies are reporting the significant dependence of wear resistance on the size of reinforcing particles [102]. Owing to the low densification level and the microstructural inhomogeneity, MMCs containing relatively coarse reinforcing particles are associated with the higher wear rate and COF [102]. In cases where the MMC microstructure contains un-melted particles with a poor interfacial bonding with the matrix, separation of these particles during sliding can plow the surface and further decrease the wear resistance. The higher densification level, improved 
microstructural homogeneity, and enhanced hardness associated with MMCs with fine reinforcing particles are the factors that improve the wear resistance [102].

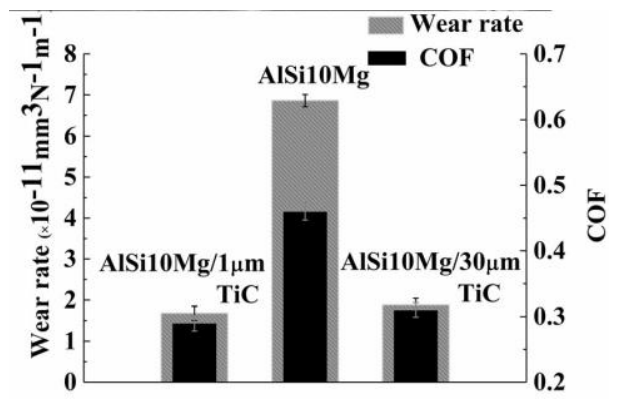

Figure 17. Wear rate and coefficient of friction (COF) for the SLM-processed non-reinforced AlSi10Mg as well as $15 \mathrm{wt} . \% \mathrm{TiC} / \mathrm{AlSi10Mg}$ composite systems with two different TiC particle size [53].

The effect of reinforcement volume fraction on wear properties of SLM-processed MMCs has been investigated in a few research studies. By increasing the hardness and decreasing the ductility, the increase in the reinforcement content up to a critical amount can lower the plastic deformation of the matrix and consequently improve the wear resistance [122]. However, fragmentation of brittle reinforcements and cracking in MMCs containing relatively high reinforcement content may prohibit further improvement or even decrease the wear resistance.

When it comes to MMCs with carbonaceous reinforcements (e.g., CNT and graphene), the reinforcements incorporated into the composite structure can improve the wear resistance due to their self-lubricating property [123,124]. During wear sliding of such composites, the easy formation of interlayer sliding and subsequent reduction of friction act to decrease the wear rate and COF (Figure 18).

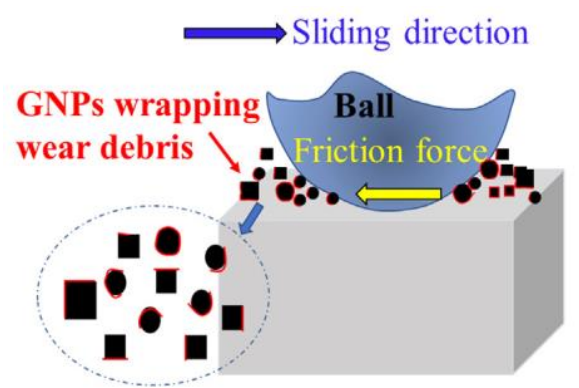

Figure 18. Schematic illustration showing the abrasive wear mechanism responsible for the influence of graphene nano-platelets (GNPs) on COF and wear resistance of GNPs/AlSi10Mg composites [69].

\section{Conclusions}

In this review, the feasibility of utilizing SLM-fabricated TMCs and AMCs in the aerospace industry is explored. To meet the requirements of the aerospace industry, the manufactured composites were characterized in terms of densification level, surface quality, hardness, strength-to-weight ratio, ductility, and wear resistance. Compared to the non-reinforced state, MMCs generally show an inferior densification level. These are believed to be the major drawbacks limiting the widespread application of MMCs, which can be resolved through employing suitable post-processing treatments such as HIP and machining. On the other hand, improved mechanical properties can be achieved by proper selection of the reinforcing particles. While the addition of the micro-scale reinforcing particles acts to enhance the hardness, wear resistance, and compressive strength, it deteriorates the ductility. When it comes to MMCs benefiting from nano-scale reinforcements, not only the hardness and strength but also the ductility can be improved. The lessons learned from this study can help to remove the obstacles facing the manufacturing of high-performance MMCs applicable in the aerospace industry. 
Author Contributions: E.F. and A.G. writing—original draft preparation, E.F. and A.G. writing-review and editing, M.E. supervision. All authors have read and agreed to the published version of the manuscript.

Funding: This research received no external funding.

Conflicts of Interest: The authors declare no conflict of interest.

\section{References}

1. Fereiduni, E.; Yakout, M.; Elbestawi, M. Laser-Based Additive Manufacturing of Lightweight Metal Matrix Composites. In Additive Manufacturing of Emerging Materials; Springer Science and Business Media: Berlin/Heidelberg, Germany, 2018; pp. 55-109.

2. Fereiduni, E.; Elbestawi, M. Process-Structure-Property Relationships in Additively Manufactured Metal Matrix Composites. In Additive Manufacturing of Emerging Materials; Springer Science and Business Media: Berlin/Heidelberg, Germany, 2018; pp. 111-177.

3. Kaczmar, J.; Pietrzak, K.; Włosiński, W. The production and application of metal matrix composite materials. J. Mater. Process. Technol. 2000, 106, 58-67. [CrossRef]

4. Miracle, D. Metal matrix composites-From science to technological significance. Compos. Sci. Technol. 2005, 65, 2526-2540. [CrossRef]

5. Borgonovo, C.; Apelian, D. Manufacture of Aluminum Nanocomposites: A Critical Review. Mater. Sci. Forum 2011, 678, 1-22. [CrossRef]

6. Chawla, K. Composite materials science and engineering. Composites 1989, 20, 286. [CrossRef]

7. Jiang, L.; Li, Z.; Fan, G.; Cao, L.; Zhang, D. The use of flake powder metallurgy to produce carbon nanotube (CNT)/aluminum composites with a homogenous CNT distribution. Carbon 2012, 50, 1993-1998. [CrossRef]

8. Fereiduni, E.; Movahedi, M.; Baghdadchi, A. Ultrahigh-strength friction stir spot welds of aluminium alloy obtained by $\mathrm{Fe}_{3} \mathrm{O}_{4}$ nanoparticles. Sci. Technol. Weld. Join. 2018, 23, 63-70. [CrossRef]

9. Gupta, M.; Sharon, N.M.L. Magnesium, Magnesium Alloys, and Magnesium Composites; John Wiley \& Sons: Hoboken, NJ, USA, 2011.

10. Standard, A. F2792. 2012. Standard Terminology for Additive Manufacturing Technologies; ASTM International: West Conshohocken, PA, USA, 2012. [CrossRef]

11. Frazier, W.E. Metal Additive Manufacturing: A Review. J. Mater. Eng. Perform. 2014, 23, 1917-1928. [CrossRef]

12. ISO. ISO 17296-2:2015, Additive Manufacturing-General Principles_Part 2: Overview of Process Categories and Feedstock; ISO: Geneva, Switzerland, 2015.

13. Shapiro, A.A.; Borgonia, J.P.; Chen, Q.N.; Dillon, R.P.; McEnerney, B.; Polit-Casillas, R.; Soloway, L. Additive Manufacturing for Aerospace Flight Applications. J. Spacecr. Rocket. 2016, 53, 952-959. [CrossRef]

14. Torres, R.; Snoeij, P.; Geudtner, D.; Bibby, D.; Davidson, M.; Attema, E.; Potin, P.; Rommen, B.; Floury, N.; Brown, M.; et al. GMES Sentinel-1 mission. Remote. Sens. Environ. 2012, 120, 9-24. [CrossRef]

15. Brandt, M.; Sun, S.; Leary, M.; Feih, S.; Elambasseril, J.; Liu, Q.C. High-Value SLM Aerospace Components: From Design to Manufacture. Adv. Mater. Res. 2013, 633, 135-147. [CrossRef]

16. English, C.L.; Tewari, S.K.; Abbott, D.H. An Overview of Ni Base Additive Fabrication Technologies for Aerospace Applications. In Proceedings of the 7th International Symposium on Superalloy 718 and Derivatives, Pittsburgh, PA, USA, 10-13 October 2010.

17. Seabra, M.; Azevedo, J.; Araújo, A.; Reis, L.; Pinto, E.; Alves, N.; Santos, R.; Mortágua, J.P. Selective laser melting (SLM) and topology optimization for lighter aerospace componentes. Procedia Struct. Integr. 2016, 1, 289-296. [CrossRef]

18. Debroy, T.; Wei, H.; Zuback, J.; Mukherjee, T.; Elmer, J.; Milewski, J.; Beese, A.M.; Wilson-Heid, A.; De, A.; Zhang, W. Additive manufacturing of metallic components-Process, structure and properties. Prog. Mater. Sci. 2018, 92, 112-224. [CrossRef]

19. Rosen, D.W. Computer-Aided Design for Additive Manufacturing of Cellular Structures. Comput. Des. Appl. 2007, 4, 585-594. [CrossRef]

20. Attaran, M. The rise of 3-D printing: The advantages of additive manufacturing over traditional manufacturing. Bus. Horiz. 2017, 60, 677-688. [CrossRef]

21. Herderick, E. Additive manufacturing of metals: A review. Mater. Sci. Technol. 2011, 2, 1413-1425. 
22. Fish, S.; Booth, J.C.; Kubiak, S.T.; Wroe, W.W.; Bryant, A.D.; Moser, D.R.; Beaman, J.J. Design and subsystem development of a high temperature selective laser sintering machine for enhanced process monitoring and control. Addit. Manuf. 2015, 5, 60-67. [CrossRef]

23. Kanko, J.A.; Sibley, A.P.; Fraser, J.M. In Situ morphology-based defect detection of selective laser melting through inline coherent imaging. J. Mater. Process. Technol. 2016, 231, 488-500. [CrossRef]

24. Pollock, T.M. Alloy design for aircraft engines. Nat. Mater. 2016, 15, 809-815. [CrossRef]

25. Popovich, V.; Borisov, E.; Popovich, A.; Sufiiarov, V.; Masaylo, D.; Alzina, L. Functionally graded Inconel 718 processed by additive manufacturing: Crystallographic texture, anisotropy of microstructure and mechanical properties. Mater. Des. 2017, 114, 441-449. [CrossRef]

26. Loh, G.H.; Eujin, P.; Harrison, D.; Monzón, M. An overview of functionally graded additive manufacturing. Addit. Manuf. 2018, 23, 34-44. [CrossRef]

27. Gibson, I.; Rosen, D.W.; Stucker, B. Design for additive manufacturing. In Additive Manufacturing Technologies; Springer: Berlin/Heidelberg, Germany, 2010; pp. 299-332.

28. Cozmei, C.; Caloian, F. Additive Manufacturing Flickering at the Beginning of Existence. Procedia Econ. Financ. 2012, 3, 457-462. [CrossRef]

29. Baumers, M.; Tuck, C.; Hague, R.; Ashcroft, I.; Wildman, R. A comparative study of metallic additive manufacturing power consumption. In Proceedings of the Solid Freeform Fabrication Symposium, 2010; pp. 278-288. Available online: https://www.tib.eu/en/search/id/BLCP\%3ACN077986101/A-ComparativeStudy-of-Metallic-Additive-Manufacturing/ (accessed on 11 June 2020).

30. Pal, S.; Lojen, G.; Kokol, V.; Drstvensek, I. Evolution of metallurgical properties of Ti-6Al-4V alloy fabricated in different energy densities in the Selective Laser Melting technique. J. Manuf. Process. 2018, 35, 538-546. [CrossRef]

31. Kasperovich, G.; Haubrich, J.; Gussone, J.; Requena, G. Correlation between porosity and processing parameters in TiAl6V4 produced by selective laser melting. Mater. Des. 2016, 105, 160-170. [CrossRef]

32. Kabir, M.R.; Richter, H. Modeling of Processing-Induced Pore Morphology in an Additively-Manufactured Ti-6Al-4V Alloy. Materials 2017, 10, 145. [CrossRef] [PubMed]

33. Sing, S.L.; Wiria, F.E.; Yeong, W.Y. Selective laser melting of titanium alloy with $50 \mathrm{wt} \%$ tantalum: Effect of laser process parameters on part quality. Int. J. Refract. Met. Hard Mater. 2018, 77, 120-127. [CrossRef]

34. Strano, G.; Hao, L.; Everson, R.; Evans, K.E. Surface roughness analysis, modelling and prediction in selective laser melting. J. Mater. Process. Technol. 2013, 213, 589-597. [CrossRef]

35. Greitemeier, D.; Donne, C.D.; Syassen, F.; Eufinger, J.; Melz, T. Effect of surface roughness on fatigue performance of additive manufactured Ti-6Al-4V. Mater. Sci. Technol. 2016, 32, 629-634. [CrossRef]

36. Koli, D.K.; Agnihotri, G.; Purohit, R. Advanced Aluminium Matrix Composites: The Critical Need of Automotive and Aerospace Engineering Fields. Mater. Today Proc. 2015, 2, 3032-3041. [CrossRef]

37. Carroll, B.E.; Palmer, T.A.; Beese, A.M. Anisotropic tensile behavior of Ti-6Al-4V components fabricated with directed energy deposition additive manufacturing. Acta Mater. 2015, 87, 309-320. [CrossRef]

38. Thijs, L.; Sistiaga, M.L.M.; Wauthle, R.; Xie, Q.; Kruth, J.-P.; Van Humbeeck, J. Strong morphological and crystallographic texture and resulting yield strength anisotropy in selective laser melted tantalum. Acta Mater. 2013, 61, 4657-4668. [CrossRef]

39. Wang, Z.; Palmer, T.A.; Beese, A.M. Effect of processing parameters on microstructure and tensile properties of austenitic stainless steel $304 \mathrm{~L}$ made by directed energy deposition additive manufacturing. Acta Mater. 2016, 110, 226-235. [CrossRef]

40. Kunze, K.; Etter, T.; Grässlin, J.; Shklover, V. Texture, anisotropy in microstructure and mechanical properties of IN738LC alloy processed by selective laser melting (SLM). Mater. Sci. Eng. A 2015, 620, 213-222. [CrossRef]

41. Sterling, A.J.; Torries, B.; Shamsaei, N.; Thompson, S.M.; Seely, D.W. Fatigue behavior and failure mechanisms of direct laser deposited Ti-6Al-4V. Mater. Sci. Eng. A 2016, 655, 100-112. [CrossRef]

42. Čapek, J.; Machová, M.; Fousová, M.; Kubásek, J.; Vojtěch, D.; Fojt, J.; Jablonska, E.; Lipov, J.; Ruml, T. Highly porous, low elastic modulus 316L stainless steel scaffold prepared by selective laser melting. Mater. Sci. Eng. C 2016, 69, 631-639. [CrossRef] [PubMed]

43. Khaing, M.; Fuh, J.; Lu, L. Direct metal laser sintering for rapid tooling: Processing and characterisation of EOS parts. J. Mater. Process. Technol. 2001, 113, 269-272. [CrossRef]

44. Mangano, C.; Chambrone, L.; Van Noort, R.; Miller, C.; Hatton, P.V.; Mangano, C. Direct Metal Laser Sintering Titanium Dental Implants: A Review of the Current Literature. Int. J. Biomater. 2014, 2014, 1-11. [CrossRef] 
45. Grünberger, T.; Domröse, R. Direct Metal Laser Sintering. Laser Tech. J. 2015, 12, 45-48. [CrossRef]

46. Pohl, H.; Simchi, A.; Issa, M.; Dias, H.C. Thermal Stresses in Direct Metal Laser Sintering. In Proceedings of the 12th Solid Freeform Fabrication Symposium, Austin, TX, USA, 6-8 August 2001.

47. De-Damborenea, J.; Arenas, M.; LaRosa, M.A.; Jardini, A.L.; Zavaglia, C.A.D.C.; Conde, A. Corrosion of Ti6Al4V pins produced by direct metal laser sintering. Appl. Surf. Sci. 2017, 393, 340-347. [CrossRef]

48. Manfredi, D.; Calignano, F.; Krishnan, M.; Canali, R.; Paola, E.; Biamino, S.; Ugues, D.; Pavese, M.; Fino, P. Additive Manufacturing of Al Alloys and Aluminium Matrix Composites (AMCs). In Light Metal Alloys Applications; IntechOpen: London, UK, 2014.

49. Zheng, L.; Zhang, M.; Chellali, R.; Dong, J. Investigations on the growing, cracking and spalling of oxides scales of powder metallurgy Rene95 nickel-based superalloy. Appl. Surf. Sci. 2011, 257, 9762-9767. [CrossRef]

50. Chang, K.; Gu, D. Direct metal laser sintering synthesis of carbon nanotube reinforced Ti matrix composites: Densification, distribution characteristics and properties. J. Mater. Res. 2016, 31, 281-291. [CrossRef]

51. Fereiduni, E.; Ghasemi, A.; Elbestawi, M. Selective laser melting of hybrid ex-situ/in-situ reinforced titanium matrix composites: Laser/powder interaction, reinforcement formation mechanism, and non-equilibrium microstructural evolutions. Mater. Des. 2019, 184, 108185. [CrossRef]

52. Fereiduni, E.; Ghasemi, A.; Elbestawi, M. Characterization of Composite Powder Feedstock from Powder Bed Fusion Additive Manufacturing Perspective. Materials 2019, 12, 3673. [CrossRef]

53. Zhou, S.Y.; Wang, Z.Y.; Su, Y.; Wang, H.; Liu, G.; Song, T.T.; Yan, M. Effects of Micron/Submicron TiC on Additively Manufactured AlSi10Mg: A Comprehensive Study from Computer Simulation to Mechanical and Microstructural Analysis. JOM J. Miner. Met. Mater. Soc. 2020, 1-12. [CrossRef]

54. Yu, W.; Sing, S.; Chua, C.; Kuo, C.-N.; Tian, X. Particle-reinforced metal matrix nanocomposites fabricated by selective laser melting: A state of the art review. Prog. Mater. Sci. 2019, 104, 330-379. [CrossRef]

55. Xi, L.; Wang, P.; Prashanth, K.; Li, H.; Prykhodko, H.; Scudino, S.; Gokuldoss, P.K. Effect of TiB 2 particles on microstructure and crystallographic texture of Al-12Si fabricated by selective laser melting. J. Alloys Compd. 2019, 786, 551-556. [CrossRef]

56. Li, X.; Ji, G.; Chen, Z.; Addad, A.; Wu, Y.; Wang, H.; Vleugels, J.; Van Humbeeck, J.; Kruth, J. Selective laser melting of nano-TiB 2 decorated AlSi10Mg alloy with high fracture strength and ductility. Acta Mater. 2017, 129, 183-193. [CrossRef]

57. Zhou, W.; Sun, X.; Kikuchi, K.; Nomura, N.; Yoshimi, K.; Kawasaki, A. Carbon nanotubes as a unique agent to fabricate nanoceramic/metal composite powders for additive manufacturing. Mater. Des. 2018, 137, 276-285. [CrossRef]

58. Li, M.; Fang, A.; Martinez-Franco, E.; Alvarado-Orozco, J.M.; Pei, Z.; Ma, C. Selective laser melting of metal matrix composites: Feedstock powder preparation by electroless plating. Mater. Lett. 2019, 247, 115-118. [CrossRef]

59. Suryanarayana, C. Mechanical alloying and milling. Prog. Mater. Sci. 2001,46,1-184. [CrossRef]

60. Cleary, P.W.; Sawley, M.L. DEM modelling of industrial granular flows: 3D case studies and the effect of particle shape on hopper discharge. Appl. Math. Model. 2002, 26, 89-111. [CrossRef]

61. Karapatis, N.; Egger, G.; Gygax, P.; Glardon, R. Optimization of powder layer density in selective laser sintering. In Proceedings of the 10th Solid Freeform Fabrication Symposium (SFF), Austin, TX, USA, 9-11 August 1999.

62. Cleary, P.W. The effect of particle shape on simple shear flows. Powder Technol. 2008, 179, 144-163. [CrossRef]

63. Ghadiri, M.; Pasha, M.; Nan, W.; Hare, C.; Vivacqua, V.; Zafar, U.; Nezamabadi, S.; Lopez, A.; Pasha, M.; Nadimi, S. Cohesive Powder Flow: Trends and Challenges in Characterisation and Analysis. KONA Powder Part. J. 2020, 37, 3-18. [CrossRef]

64. Gu, D.; Wang, H.; Dai, D. Laser Additive Manufacturing of Novel Aluminum Based Nanocomposite Parts: Tailored Forming of Multiple Materials. J. Manuf. Sci. Eng. 2015, 138, 021004. [CrossRef]

65. Chen, M.; Li, X.; Ji, G.; Wu, Y.; Chen, Z.; Baekelant, W.; Vanmeensel, K.; Wang, H.; Kruth, J.-P. Novel Composite Powders with Uniform $\mathrm{TiB}_{2}$ Nano-Particle Distribution for 3D Printing. Appl. Sci. 2017, 7, 250. [CrossRef]

66. Wang, P.; Gammer, C.; Brenne, F.; Niendorf, T.; Eckert, J.; Scudino, S. A heat treatable TiB $2 /$ Al-3.5 Cu-1.5 $\mathrm{Mg}$-1Si composite fabricated by selective laser melting: Microstructure, heat treatment and mechanical properties. Compos. Part B Eng. 2018, 147, 162-168. [CrossRef] 
67. Lin, T.-C.; Cao, C.; Sokoluk, M.; Jiang, L.; Wang, X.; Schoenung, J.M.; Lavernia, E.J.; Li, X. Aluminum with dispersed nanoparticles by laser additive manufacturing. Nat. Commun. 2019, 10,1-9. [CrossRef]

68. Wang, M.; Song, B.; Wei, Q.; Shi, Y. Improved mechanical properties of AlSi7Mg/nano-SiCp composites fabricated by selective laser melting. J. Alloys Compd. 2019, 810, 151926. [CrossRef]

69. Wu, L.; Zhao, Z.; Bai, P.; Zhao, W.; Li, Y.; Liang, M.; Liao, H.; Huo, P.; Li, J. Wear resistance of graphene nano-platelets (GNPs) reinforced AlSi10Mg matrix composite prepared by SLM. Appl. Surf. Sci. 2020, 503, 144156. [CrossRef]

70. Jiang, L.; Liu, T.; Zhang, C.; Zhang, K.; Li, M.; Ma, T.; Liao, W. Preparation and mechanical properties of CNTs-AlSi10Mg composite fabricated via selective laser melting. Mater. Sci. Eng. A 2018, 734, 171-177. [CrossRef]

71. Liao, H.; Zhu, H.; Xue, G.; Zeng, X. Alumina loss mechanism of $\mathrm{Al}_{2} \mathrm{O}_{3}$-AlSi10Mg composites during selective laser melting. J. Alloys Compd. 2019, 785, 286-295. [CrossRef]

72. Xiao, Y.; Bian, Z.; Wu, Y.; Ji, G.; Li, Y.; Li, M.; Lian, Q.; Chen, Z.; Addad, A.; Wang, H. Effect of nano-TiB 2 particles on the anisotropy in an AlSi10Mg alloy processed by selective laser melting. J. Alloys Compd. 2019, 798, 644-655. [CrossRef]

73. Zhao, Z.; Bai, P.; Misra, R.; Dong, M.; Guan, R.; Li, Y.; Zhang, J.; Tan, L.; Gao, J.; Ding, T.; et al. AlSi10Mg alloy nanocomposites reinforced with aluminum-coated graphene: Selective laser melting, interfacial microstructure and property analysis. J. Alloys Compd. 2019, 792, 203-214. [CrossRef]

74. Xue, G.; Ke, L.; Zhu, H.; Liao, H.; Zhu, J.; Zeng, X. Influence of processing parameters on selective laser melted SiCp/AlSi10Mg composites: Densification, microstructure and mechanical properties. Mater. Sci. Eng. A 2019, 764, 138155. [CrossRef]

75. Xi, L.; Zhang, H.; Wang, P.; Li, H.; Gokuldoss, P.K.; Lin, K.; Kaban, I.; Gu, D. Comparative investigation of microstructure, mechanical properties and strengthening mechanisms of $\mathrm{Al}-12 \mathrm{Si} / \mathrm{TiB}_{2}$ fabricated by selective laser melting and hot pressing. Ceram. Int. 2018, 44, 17635-17642. [CrossRef]

76. Attar, H.; Prashanth, K.G.; Zhang, L.; Calin, M.; Okulov, I.; Scudino, S.; Yang, C.; Eckert, J. Effect of Powder Particle Shape on the Properties of In Situ Ti-TiB Composite Materials Produced by Selective Laser Melting. J. Mater. Sci. Technol. 2015, 31, 1001-1005. [CrossRef]

77. Attar, H.; Bönisch, M.; Calin, M.; Zhang, L.; Scudino, S.; Eckert, J. Selective laser melting of In Situ titanium-titanium boride composites: Processing, microstructure and mechanical properties. Acta Mater. 2014, 76, 13-22. [CrossRef]

78. Gu, D.; Hagedorn, Y.-C.; Meiners, W.; Wissenbach, K.; Poprawe, R. Nanocrystalline TiC reinforced Ti matrix bulk-form nanocomposites by Selective Laser Melting (SLM): Densification, growth mechanism and wear behavior. Compos. Sci. Technol. 2011, 71, 1612-1620. [CrossRef]

79. Li, H.; Yang, Z.; Cai, D.; Jia, D.; Zhou, Y. Microstructure evolution and mechanical properties of selective laser melted bulk-form titanium matrix nanocomposites with minor $\mathrm{B}_{4} \mathrm{C}$ additions. Mater. Des. 2020, 185, 108245. [CrossRef]

80. Li, J.; Shen, L.; Liu, Z.; Liang, H.; Li, Y.; Han, X. Microstructure, microhardness, and wear performance of zirconia reinforced pure titanium composites prepared by selective laser melting. Mater. Res. Express 2018, 6, 036520. [CrossRef]

81. Kang, N.; Coddet, P.; Liu, Q.; Liao, H.; Coddet, C. In-situ TiB/near $\alpha$ Ti matrix composites manufactured by selective laser melting. Addit. Manuf. 2016, 11,1-6. [CrossRef]

82. Liu, Y.; Li, S.; Misra, R.; Geng, K.; Yang, Y. Planting carbon nanotubes within Ti-6Al-4V to make high-quality composite powders for 3D printing high-performance Ti-6Al-4V matrix composites. Scr. Mater. 2020, 183, 6-11. [CrossRef]

83. Tjong, S.C. Recent progress in the development and properties of novel metal matrix nanocomposites reinforced with carbon nanotubes and graphene nanosheets. Mater. Sci. Eng. R Rep. 2013, 74, 281-350. [CrossRef]

84. Nieto, A.; Bisht, A.; Lahiri, D.; Zhang, C.; Agarwal, A. Graphene reinforced metal and ceramic matrix composites: A review. Int. Mater. Rev. 2016, 62, 1-62. [CrossRef]

85. Mukherjee, T.; Zuback, J.S.; De, A.; Debroy, T. Printability of alloys for additive manufacturing. Sci. Rep. 2016, 6, 19717. [CrossRef] [PubMed]

86. Thijs, L.; Verhaeghe, F.; Craeghs, T.; Van Humbeeck, J.; Kruth, J.-P. A study of the microstructural evolution during selective laser melting of Ti-6Al-4V. Acta Mater. 2010, 58, 3303-3312. [CrossRef] 
87. Seifi, M.; Salem, A.; Beuth, J.; Harrysson, O.; Lewandowski, J. Overview of Materials Qualification Needs for Metal Additive Manufacturing. JOM 2016, 68, 747-764. [CrossRef]

88. Wang, Y.; Shi, J.; Lu, S.; Xiao, W. Investigation of Porosity and Mechanical Properties of Graphene Nanoplatelets-Reinforced AlSi10Mg by Selective Laser Melting. J. Micro Nano Manuf. 2017, 6, 010902. [CrossRef]

89. Ghosh, S.K.; Saha, P.; Kishore, S. Influence of size and volume fraction of SiC particulates on properties of ex situ reinforced $\mathrm{Al}-4.5 \mathrm{Cu}-3 \mathrm{Mg}$ metal matrix composite prepared by direct metal laser sintering process. Mater. Sci. Eng. A 2010, 527, 4694-4701. [CrossRef]

90. Niu, H.; Chang, I. Instability of scan tracks of selective laser sintering of high speed steel powder. Scr. Mater. 1999, 41, 1229-1234. [CrossRef]

91. Mumtaz, K.; Hopkinson, N. Top surface and side roughness of Inconel 625 parts processed using selective laser melting. Rapid Prototyp. J. 2009, 15, 96-103. [CrossRef]

92. Simchi, A.; Godlinski, D. Effect of SiC particles on the laser sintering of Al-7Si-0.3Mg alloy. Scr. Mater. 2008, 59, 199-202. [CrossRef]

93. Gu, D.; Yuan, P. Thermal evolution behavior and fluid dynamics during laser additive manufacturing of Al-based nanocomposites: Underlying role of reinforcement weight fraction. J. Appl. Phys. 2015, 118, 233109. [CrossRef]

94. Attar, H.; Calin, M.; Zhang, L.; Scudino, S.; Eckert, J. Manufacture by selective laser melting and mechanical behavior of commercially pure titanium. Mater. Sci. Eng. A 2014, 593, 170-177. [CrossRef]

95. Gu, D.D.; Meiners, W.; Wissenbach, K.; Poprawe, R. Laser additive manufacturing of metallic components: Materials, processes and mechanisms. Int. Mater. Rev. 2012, 57, 133-164. [CrossRef]

96. Gong, H.; Rafi, K.; Gu, H.; Starr, T.; Stucker, B. Analysis of defect generation in Ti-6Al-4V parts made using powder bed fusion additive manufacturing processes. Addit. Manuf. 2014, 1, 87-98. [CrossRef]

97. Khorasani, A.; Gibson, I.; Ghasemi, A.; Ghaderi, A. A comprehensive study on variability of relative density in selective laser melting of Ti-6Al-4V. Virtual Phys. Prototyp. 2019, 14, 349-359. [CrossRef]

98. Laquai, R.; Müller, B.R.; Kasperovich, G.; Haubrich, J.; Requena, G.; Bruno, G. X-ray refraction distinguishes unprocessed powder from empty pores in selective laser melting Ti-6Al-4V. Mater. Res. Lett. 2017, 6, 130-135. [CrossRef]

99. Shi, X.; Ma, S.; Liu, C.; Chen, C.; Wu, Q.; Chen, X.; Jiping, L. Performance of High Layer Thickness in Selective Laser Melting of Ti6Al4V. Materials 2016, 9, 975. [CrossRef]

100. Simchi, A. Direct laser sintering of metal powders: Mechanism, kinetics and microstructural features. Mater. Sci. Eng. A 2006, 428, 148-158. [CrossRef]

101. Simchi, A.; Godlinski, D. Densification and microstructural evolution during laser sintering of A356/SiC composite powders. J. Mater. Sci. 2011, 46, 1446-1454. [CrossRef]

102. Chang, F.; Gu, D.; Dai, D.; Yuan, P. Selective laser melting of in-situ Al4SiC4 + SiC hybrid reinforced Al matrix composites: Influence of starting SiC particle size. Surf. Coat. Technol. 2015, 272, 15-24. [CrossRef]

103. Ma, C.; Gu, D.; Dai, D.; Chen, W.; Chang, F.; Yuan, P.; Shen, Y. Aluminum-based nanocomposites with hybrid reinforcements prepared by mechanical alloying and selective laser melting consolidation. J. Mater. Res. 2015, 30, 2816-2828. [CrossRef]

104. Ghosh, S.K.; Bandyopadhyay, K.; Saha, P. Development of an in-situ multi-component reinforced Al-based metal matrix composite by direct metal laser sintering technique-Optimization of process parameters. Mater. Charact. 2014, 93, 68-78. [CrossRef]

105. Jue, J.; Gu, D.; Chang, K.; Dai, D. Microstructure evolution and mechanical properties of $\mathrm{Al}_{-} \mathrm{Al}_{2} \mathrm{O}_{3}$ composites fabricated by selective laser melting. Powder Technol. 2017, 310, 80-91. [CrossRef]

106. Gu, D.; Wang, H.; Dai, D.; Chang, F.; Meiners, W.; Hagedorn, Y.-C.; Wissenbach, K.; Kelbassa, I.; Poprawe, R. Densification behavior, microstructure evolution, and wear property of TiC nanoparticle reinforced AlSi10Mg bulk-form nanocomposites prepared by selective laser melting. J. Laser Appl. 2015, 27, S17003. [CrossRef]

107. Gu, D.; Meng, G.; Li, C.; Meiners, W.; Poprawe, R. Selective laser melting of TiC/Ti bulk nanocomposites: Influence of nanoscale reinforcement. Scr. Mater. 2012, 67, 185-188. [CrossRef]

108. Hong, C.; Gu, D.; Dai, D.; AlKhayat, M.; Urban, W.; Yuan, P.; Cao, S.; Gasser, A.; Weisheit, A.; Kelbassa, I.; et al. Laser additive manufacturing of ultrafine TiC particle reinforced Inconel 625 based composite parts: Tailored microstructures and enhanced performance. Mater. Sci. Eng. A 2015, 635, 118-128. [CrossRef] 
109. Song, B.; Dong, S.; Coddet, P.; Zhou, G.; Ouyang, S.; Liao, H.; Coddet, C. Microstructure and tensile behavior of hybrid nano-micro $\mathrm{SiC}$ reinforced iron matrix composites produced by selective laser melting. J. Alloys Compd. 2013, 579, 415-421. [CrossRef]

110. Song, B.; Dong, S.; Coddet, C. Rapid In Situ fabrication of Fe/SiC bulk nanocomposites by selective laser melting directly from a mixed powder of microsized Fe and SiC. Scr. Mater. 2014, 75, 90-93. [CrossRef]

111. Askeland, D.R.; Haddleton, F.; Green, P.; Robertson, H. The Science and Engineering of Materials; Springer: Dordrecht, The Netherlands, 2003.

112. Martin, J.H.; Yahata, B.D.; Hundley, J.M.; Mayer, J.; Schaedler, T.A.; Pollock, T.M. 3D printing of high-strength aluminium alloys. Nature 2017, 549, 365-369. [CrossRef]

113. Dadbakhsh, S.; Hao, L. Effect of Al alloys on selective laser melting behaviour and microstructure of In Situ formed particle reinforced composites. J. Alloys Compd. 2012, 541, 328-334. [CrossRef]

114. Schmauder, S.; Köhler, C. Atomistic simulations of solid solution strengthening of $\alpha$-iron. Comput. Mater. Sci. 2011, 50, 1238-1243. [CrossRef]

115. Gokuldoss, P.K.; Scudino, S.; Chaubey, A.K.; Löber, L.; Wang, P.; Attar, H.; Schimansky, F.P.; Pyczak, F.; Eckert, J.; Gokuldoss, P.K. Processing of Al-12Si-TNM composites by selective laser melting and evaluation of compressive and wear properties. J. Mater. Res. 2015, 31, 55-65. [CrossRef]

116. Gopagoni, S.; Hwang, J.; Singh, A.; Mensah, B.; Bunce, N.; Tiley, J.; Scharf, T.W.; Banerjee, R. Microstructural evolution in laser deposited nickel-titanium-carbon In Situ metal matrix composites. J. Alloys Compd. 2011, 509, 1255-1260. [CrossRef]

117. Gu, D.; Chang, F.; Dai, D. Selective Laser Melting Additive Manufacturing of Novel Aluminum Based Composites With Multiple Reinforcing Phases. J. Manuf. Sci. Eng. 2015, 137, 021010. [CrossRef]

118. Gu, D. Novel Aluminum Based Composites by Selective Laser Melting (SLM) Additive Manufacturing (AM): Tailored Formation of Multiple Reinforcing Phases and its Mechanisms. In Laser Additive Manufacturing of High-Performance Materials; Springer Science and Business Media: Berlin/Heidelberg, Germany, 2015; pp. 201-222.

119. Cao, S.; Gu, D.; Shi, Q. Relation of microstructure, microhardness and underlying thermodynamics in molten pools of laser melting deposition processed TiC/Inconel 625 composites. J. Alloys Compd. 2017, 692, 758-769. [CrossRef]

120. Dadbakhsh, S.; Hao, L. In Situ Formation of Particle Reinforced Al Matrix Composite by Selective Laser Melting of $\mathrm{Al} / \mathrm{Fe}_{2} \mathrm{O}_{3}$ Powder Mixture. Adv. Eng. Mater. 2011, 14, 45-48. [CrossRef]

121. Han, Q.; Geng, Y.; Setchi, R.; Lacan, F.; Gu, D.; Evans, S. Macro and nanoscale wear behaviour of $\mathrm{Al}_{-}-\mathrm{Al}_{2} \mathrm{O}_{3}$ nanocomposites fabricated by selective laser melting. Compos. Part B Eng. 2017, 127, 26-35. [CrossRef]

122. Ghosh, S.K.; Saha, P. Crack and wear behavior of $\mathrm{SiC}$ particulate reinforced aluminium based metal matrix composite fabricated by direct metal laser sintering process. Mater. Des. 2011, 32, 139-145. [CrossRef]

123. Xu, Z.; Shi, X.; Zhai, W.; Yao, J.; Song, S.; Zhang, Q. Preparation and tribological properties of TiAl matrix composites reinforced by multilayer graphene. Carbon 2014, 67, 168-177. [CrossRef]

124. Moghadam, A.D.; Omrani, E.; Menezes, P.L.; Rohatgi, P.K. Mechanical and tribological properties of self-lubricating metal matrix nanocomposites reinforced by carbon nanotubes (CNTs) and grapheme-A review. Compos. Part B Eng. 2015, 77, 402-420. [CrossRef]

(C) 2020 by the authors. Licensee MDPI, Basel, Switzerland. This article is an open access article distributed under the terms and conditions of the Creative Commons Attribution (CC BY) license (http://creativecommons.org/licenses/by/4.0/). 